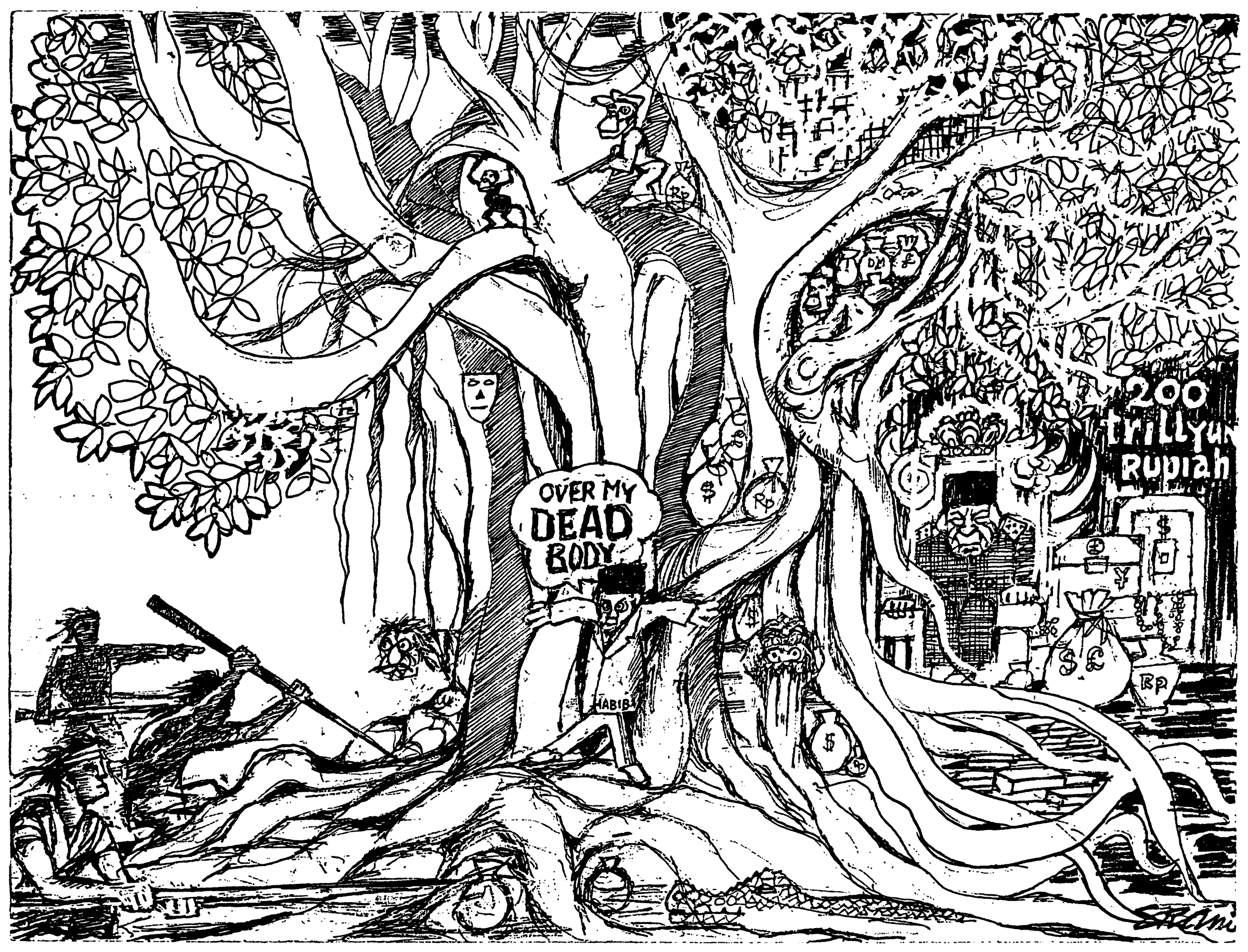




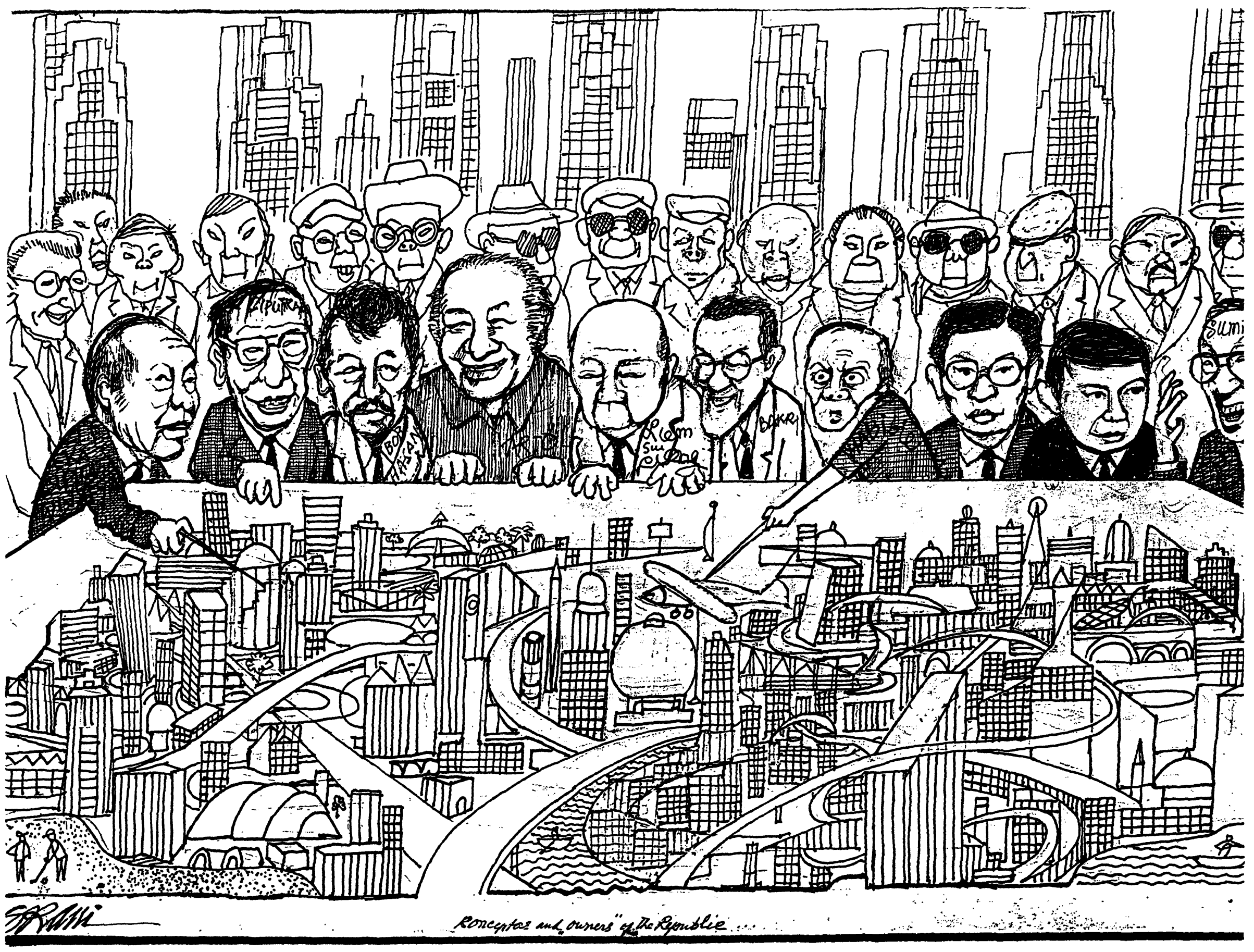




\title{
MACET TOTAL: LOGICS OF CIRCULATION AND ACCUMULATION IN THE DEMISE OF INDONESIA'S NEW ORDER
}

\section{John T. Sidel ${ }^{1}$}

\begin{abstract}
The streets of today's Jakarta are not meant for pedestrians. The commuters in their automobiles and the pedestrians live in two separate worlds.... Walking on the streets means that one has no access to a car, no access to a protective network, and no access to anybody anywhere. What such people carry with them is all they have. Jakartans in their passing cars, on the other hand, incessantly run around the city, back and forth, round and round, busily tracing the mentally constructed route-maps and reenacting ties organized hierarchically into the network.
\end{abstract}

\section{Saya S. Shiraishi, Young Heroes: The Indonesian Family in Politics ${ }^{2}$}

\section{Introduction: A Nation of One-Way Streets}

For a visitor to a major Indonesian city like Surabaya in the final years of the Suharto era, the pattern of vehicular traffic made for a strikingly odd contrast with big boomtowns elsewhere in Southeast Asia. In this city of nearly four million residents,

1 The author would like to thank Joshua Barker, Arief Djati, Lotta Hedman, and Benny Subianto for their encouragment, insight, and inspiration from the conception of this essay to its eventual completion, as well as Ben Anderson, Anne Booth, Howard Dick, Vedi Hadiz, Douglas Kammen, Mike Malley, Jonathan Pincus, Loren Ryter, and Takashi Shiraishi for their comments, suggestions, and constructive criticisms on/of an earlier draft. Financial support for research in Indonesia was provided by the School of Oriental and African Studies, University of London, and the South East Asia Committee of the British Academy. Responsibility for errors of fact and judgment rests solely with the author.

2 Saya S. Shiraishi, Young Heroes: The Indonesian Family in Politics (Ithaca: Cornell Southeast Asia Program, 1997), pp. 27, 30. 
160 John T. Sidel

Indonesia's second largest metropolis and industrial hub, the number of stop-lights and four-way intersections could virtually be counted on one hand. Almost always uni-directional in terms of traffic, the main boulevards of Surabaya were rarely unilinear. Instead, even major arteries of the city tended to snake around the four points of the compass, forking or fading smoothly into other thoroughfares with hardly a ripple in the remarkably steady stream of one-way traffic.

Indeed, the effect was to minimize the frequency and length of traffic jamskemacetan or simply macet-and to maximize the ease and fluidity of traffic circulation. Frequent local newspaper articles in the 1980 s and early 1990 s attested to the assiduous efforts of the Surabaya city government to this end, rerouting traffic in new directions, on new streets, to meet the ever rising flow of auto vehicles in the metropolis. One-way streets, it seemed, were the key: as a bemo (public minibus) driver explained to the author in the autumn of 1997, Indonesian drivers could hardly be trusted to handle two-way streets without creating a mess. Transportation routes might often seem excessively circuitous, with pedestrians condemned to rare overpasses and mad dashes across busy boulevards, but the traffic rarely came to a complete standstill.

Thus when traffic did grind to a halt, when macet occurred, there was always a palpable sense of interest in the source of the problem, heads popping out of car windows, raised eyebrows and shared nervous glances among passengers in the bemo. On such occasions it was easy to grasp what John Pemberton described in his nuanced account of the 1982 election campaign in the city of Solo: the omen of "an approaching $s a^{\prime} a t$, a moment when something might happen . . . a sense that carried with it all the fascination of an enormous political traffic accident." 3

Perhaps, as Pemberton's comments suggested, the pattern of traffic in late-New Order cities like Surabaya reflected deeper patterns in the workings-and the unravelling - of the Suharto regime. Indeed, Suharto's success in consolidating power in the late 1960 s and early 1970 s owed much to the massive reinfusion of foreign capital into the circuitries of the Indonesian economy and the rapid recirculation of rival military officers within the corridors of the Indonesian state. Suharto's durability in the 1980s and 1990s, moreover, likewise rested to a considerable extent on the continued mutasi and regenerasi of the Armed Forces officer corps and, with the end of the oil boom, the accelerated inward flows of foreign direct investment and outward flows of manufactured goods. Like the painted mannequin policemen standing watchfully at key road junctions in Surabaya to oversee the traffic, Suharto presided over the continuous flow of capital, labor, and commodities, and the regular rotation of military and civilian personnel. It was precisely this steady circulation (sirkulasi)—of bank loans, oil drums, export containers, high school and university graduates, parliamentarians, bupatis, and Army officers-along one-way streets that kept Indonesia in motion as Suharto stood still, for more than thirty years.

Yet the costs and the limits of such sirkulasi were apparent to all who could sense the possibility of macet. After all, the constant refashioning of Surabaya's thoroughfares had engendered countless local neighborhood protests in the city, and throughout Indonesia, the inroads of New Order state and capital had left bitter resentments in their wake. The forced removal of becak (pedicab) drivers from main Jakarta streets in

3 John Pemberton, On the Subject of "Java" (Ithaca: Cornell University Press, 1994), p. 6. 
the 1980s, the unceremonious dumping of hundreds of becak in the harbor, and the ensuing public outcry perhaps best exemplified this trend.

Suharto, moreover, was no mere mannequin traffic cop. As his centrality and durability depended very heavily on the continued circulation of personnel and constant flow of resources, logjams in capital accumulation or regime reproduction were all the more meaningful, and all the more threatening, in their implications. Hence the great salience in New Order history of key peristiwa (incidents)-the Malari riots of January 1974, the Tanjung Priok massacre in 1984, the storming of the Partai Demokrasi Indonesia (PDI) headquarters in 1996-or even seemingly minor episodes, termed interupsi, in the regime's pseudo-parliamentary bodies, such as a military delegate's outburst against vice-presidential nominee Sudharmono in the MPR (People's Consultative Assembly) in 1988. Yet like any real traffic cop, Suharto could use the threat and reality of logjams to his own purposes, both to clear traffic violators from the streets and to reaffirm the rules of circulation and the authority of their enforcers.

Seen in this light, the exact moment that signalled the unravelling of the Suharto regime may be pinpointed with great precision: the evening of May 4, 1998. With the announcement that government subsidies on fuel prices would be drastically reduced at midnight, thousands of automobile and motorbike drivers around the country lined up at gasoline stations to buy up remaining supplies of subsidized fuel. In Jakarta and Surabaya, at least, the lines for fuel extended many city blocks, bringing traffic at key junctions to a virtual standstill: macet total.

Late that night, scores of bemo and taxi drivers in downtown Surabaya converged on the regional assembly (DPRD, Dewan Perwakilan Rakyat Daerah) building to demand the restoration of fuel subsidies, and, over the following week, student protests previously confined to the university campuses spilled out into the streets for the very first time in 1998. In the three weeks after the traffic jams on the streets of Jakarta and Surabaya, the nation witnessed mass protests and looting in Medan, violent riots in Jakarta and Solo, a student occupation of the Parliament, and the resignation of President Suharto. In short, the "enormous political traffic accident" that Pemberton foretold.

A focus on the May 4, 1998 traffic jams, moreover, highlights certain lingering puzzles about the New Order's demise. President Suharto, it should be recalled, had weathered previous economic crises by bending with the winds, bowing to the demands of the IMF (International Monetary Fund) and other foreign lenders and investors, and opening up new avenues to ease and accelerate the flow of sirkulasi. 4 Yet in late 1997 and early 1998, the regime showed a striking preference for a very different approach to macet management: VIP parking and restricted entry in key arteries, staged disruptions and diversions of traffic on main boulevards, and forced removal of traffic violators from the streets. Even the decision to slash fuel subsidies (and its timing) in early May stemmed not from the specific requirements of an IMF austerity program but from these stubbornly diversionary, disruptive tactics, which, ironically,

4 Jeffrey A. Winters, Power in Motion: Capital Mobility and the Indonesian State (Ithaca: Cornell University Press, 1996). 
helped to facilitate a surprisingly fluid and orderly process of transition to a postSuharto era.

The remainder of this essay aims to explain such oddities and ironies in the demise of the New Order in terms of the logics of sirkulasi and macet in the workings of the Suharto regime. On the one hand, this essay argues, it was the underlying tension between circulation and accumulation in Suharto's New Order which set the stage for the macet total of May 1998. On the other hand, the essay suggests, the regime's own tactics for managing macet helped to shape the process and outcome of regime transition. By tracing the logics of sirkulasi and macet, this essay seeks to illuminate the final months of the Suharto era, drawing on the abundant treasures of scholarship on Indonesia's New Order as well as the pedestrian observations of this bystander on the streets of Surabaya and Jakarta during the macet total of 1998.

\section{Logics of Circulation and Accumulation}

As Pemberton argued, the Suharto regime was an essentially hybrid form of authoritarian rule, whose internal institutional contradictions provided the essential parameters for political continuity and change in Indonesia since the mid-1960s. Many observers noted the tensions between the regime's 'traditional Javanese' and modernizing tendencies in the ideological realm, its variously integralist and Islamicist approaches to ethnic and religious diversity, and its alternately liberal and statist leanings in economic policy. Yet the most important tensions within the regime, it can be argued, stemmed from the peculiar mix of institutional bases and personal networks through which Suharto entrenched himself in power and exerted authority over the more than thirty years of his rule. In this regard, one key structural tension within the regime developed between the pattern of circulation within the Armed Forces and the process of personal accumulation by the President, between the military circuitries of his regime and the more civilian networks for his electoral and ideological legitimation and his (and his family's) economic enrichment. This tension prefigured the macet to come.

As is well known, Suharto came to power in late 1965 in the wake of a coup d'état, and it was his position as commander of Kostrad, the Army Strategic Reserve Command, in Jakarta - and as one of the Army's most senior generals-that allowed him to consolidate power, both within the Armed Forces and in Indonesian society at large. Under Suharto, the Army assumed a dominant role within the Armed Forces, the state, and society, and Army officers (both active and retired) came to occupy numerous key positions as cabinet ministers, local government officials, heads of state enterprises, and members of the regime's pseudo-parliamentary bodies. Institutionally, the Armed Forces' preeminent position within the state was guaranteed through its appointed representatives in the largely rubber-stamp parliament and the MPR, the body that met every five years to "elect" the president and vice-president. 5

Over the years, even as Suharto abandoned his Army uniform for civilian attire and relinquished his long-held role as Defense Minister to successive (retired) generals,

${ }^{5} \mathrm{John}$ A. MacDougall, "Patterns of Military Control in the Indonesian Higher Central Bureaucracy," Indonesia 33 (April 1982): 89-121. 
the President retained considerable control over military promotions and assignments. However, unlike civilian autocrats such as Ferdinand Marcos in the neighboring Philippines, for example, Suharto was acutely aware of the dangers of overstaying generals and saw fit to maintain a steady pace of rotation (mutasi) and retirement. Every year, officers reaching the ripe age of fifty-five were pensioned off, usually to cushy civilian postings. The fruits of this policy were considerable, breeding not a generation of restive colonels but rather a steady stream of upwardly mobile and amply servile generals.

Yet this pattern of fluid sirkulasi gave rise to three underlying structural problems. First of all, three decades of Suharto's rule witnessed a steady erosion of the personal loyalty owed by the military leadership to the President himself. With every passing year, even as another annual batch of Armed Forces officers went into retirement at the age of fifty-five, Suharto grew older and his links to the officer corps-through shared personal, generational, and institutional experiences-grew ever more tenuous. In the late 1960 s and 1970s, Suharto could still fill the uppermost ranks of the military hierarchy with trusted lieutenants from his days as Commander of the Army's Diponegoro (Central Java) Division, the Mandala Command for the Liberation of West Irian, and Kostrad in the 1950s and early-mid 1960s. By the 1980s, however, virtually all such old Army cronies had died off, disgraced themselves, or otherwise exhausted their usefulness, and the old pattern could only be prolonged through extraordinary reliance on a single long-time protégé from a somewhat later generation, General Benny Murdani, who enjoyed unprecedented authority as Suharto's security and intelligence czar for much of the decade. ${ }^{6}$ As Benedict Anderson noted in the pages of this journal in 1985: "It is safe now to say that at no previous time in Indonesia's history has a military man on active service had such complete control of the country's fire power as General Murdani."7

Yet by the 1990s, after Benny Murdani's long postponed but perhaps inevitable demise, Suharto found himself reliant upon a military establishment dominated by officers who had risen up through the ranks with little direct personal contact with-or proven personal loyalty to-their President. To offset the horizontal solidarities and shared institutional loyalties inculcated in the military academy in the 1960s and early 1970s and reinforced over the three decades of ABRI's (Angkatan Bersenjata Republik Indonesia, The Armed Forces of the Republic of Indonesia) institutional entrenchment under the New Order, Suharto was forced to resort to the cultivation of new vertical dyadic ties with individual officers. Thus the early 1990s found him favoring senior officers with previous service, or with close personal relations with members of his own family, as his personal adjutants and bodyguards. The former trend was first apparent in the rise of former aide-de-camp General Try Sutrisno in the 1980s and his installment as Commander-in-Chief of the Armed Forces (Pangab) in 1988-1993, while the latter pattern was pioneered by Suharto's brother-in-law, Army Chief of Staff (Kasad) General Wismoyo Arismunandar (1993-95).

\footnotetext{
6 See David Jenkins, Soeharto and His Generals: Indonesian Military Politics 1975-1983 (Ithaca: Cornell Modern Indonesia Project Monograph Series No. 64, 1984).

${ }^{7}$ Ben Anderson, "Current Data on the Indonesian Military Elite," Indonesia 40 (October 1985): 136.
} 
Yet Suharto's strategy was hardly without dangers of its own. The favor shown to such well-connected officers earned the President a growing reputation for nepotism and engendered the resentment of less privileged (if avowedly more "professional") officers in the Armed Forces. Meanwhile, even those officers closest to the Palace had invariably established other strong relationships and loyalties over the years-to their military academy classmates and their former commanding officers-that competed with the fealty they owed to their President and the cluster of interests associated with the Palace. ${ }^{8}$

Secondly, from the early days of his seizure of power in 1965, Suharto had also relied on civilian networks and bases of support and on constitutional and pseudodemocratic trappings to entrench himself as President and embellish his rule. Student activists, political party networks, and parliamentary figures were cultivated in the effort to eliminate the PKI (Indonesian Communist Party) from the political scene and to engineer the dethroning of Soekarno, technocrats were enlisted to facilitate the reopening of the Indonesian economy to foreign capital, politicians (and thugs) were hired to manufacture electoral victories for Golkar and staff the regime's rubber-stamp parliament, businessmen were promoted to oil the political machine and rewire the circuitries of the domestic market.

Thus, from the beginning there were tensions between the institutional interests of the Army and the personal interests of the President and those who staffed his civilian bases of power-in the Palace, the Cabinet, Golkar, and the DPR (Dewan Perwakilan Rakyat, People's Representative Assembly), state enterprises (e.g. Pertamina) and the bureaucracy, and the business world. In the 1970s, Suharto leaned heavily on a circle of trusted lieutenants from his Army days in the Soekarno era-the so-called "financial" and "political" generals-to run the show, but by the 1980s even many upper echelons of "civilian" power had been filled by a less familiar crop of technocrats and retired Armed Forces officers recirculating along non-military bureaucratic or parliamentary career paths in their late 50s and early 60s. Thus the early 1990 s saw Suharto reasserting personal control over the upper echelons of Golkar and the bureaucracy through the installation of civilian figures close to the Palace. This pattern of favoritism in civilian appointments shared many obvious limitations and drawbacks with the parallel strategy pursued in managing the Armed Forces leadership.

Thirdly and finally, if year after year saw the rotation and retirement of yet another batch of officers, the passing of time witnessed complete stasis in the top national leadership as well as the steady accumulation of wealth and power by a small cluster of private interests associated with the President. The oil boom years of the 1970s had seen the rise of diversified conglomerates owned by close cronies of the President, typically ethnic-Chinese financiers or cukong who enjoyed close personal and business ties to Suharto for many years, and by the late 1980s men like Liem Sioe Liong and Bob Hasan had established a commanding presence in the Indonesian economy through privileged access to state loans, tax and regulatory breaks, monopoly privileges, special concessions, and countless other perks. ${ }^{9}$

\footnotetext{
8 The Editors, "Current Data on the Indonesian Military Elite: January 1, 1992-April 3, 1993," Indonesia 55 (April 1993): 180.

${ }^{9}$ Richard Robison, Indonesia: The Rise of Capital (Sydney: Allen and Unwin, 1986), pp. 271-322.
} 
By the early 1990s, moreover, as the President entered his twilight years, the (by now middle-aged) Suharto children had through similar methods accumulated enormous wealth and amassed vast business empires which spanned all major sectors of the economy. As foreign investors and bankers flooded into the country, they invariably chose members of the President's family as key partners and borrowers in major industrial, infrastructure, and real-estate projects. In short order, the Suharto children also installed themselves and their minions in top leadership positions in Golkar and, in due course, the Cabinet. ${ }^{10}$ Unlike their predecessors in these seats of power, they were certain to stay so long as Suharto remained President. Their emergence and entrenchment spelled new restrictions on sirkulasi and portended the onset of macet at the highest levels of New Order authority. Thus, by the 1990s, in contrast with all the other old soldiers who faded away in steady numbers with every passing year, Suharto stood out as the nation's sole overstaying general, pursuing dynastic accumulation rather than regenerasi at the pinnacle of state power. With his mortality and the question of presidential succession growing more urgent with every passing year, increasing pressures for turnover could be sublimated but never fully suppressed.

Thus, by the early 1990s, the competing New Order logics of circulation and accumulation had begun to foreshadow the onset of macet. Even as steady mutasi and regenerasi proceeded within the Armed Forces and into the civilian corridors of the state, stagnation in the national leadership, and accumulation and entrenchment (rather than continued circulation) by a cluster of private interests based in the Palace threatened to clog up the core arteries of the regime. Yet to understand the form which this congestion would assume in the late 1990s, it is necessary first to situate the pattern of steady sirkulasi and impending macet in the regime sketched above against the backdrop of changes in New Order society.

\section{Jaringan: Modal, Féodal, Intel (lektual), Islam}

Since the inception of the Suharto era in 1965-1966, social incorporation into the regime had proceeded through the admission and circulation of élite networks or jaringan within the key corridors of New Order power. The mode of social incorporation varied considerably from one élite network to the next, carrying major implications for their long-term capacities for circulation and accumulation under the New Order. The outer limits and internal contradictions of the regime's policies of cooptation and incorporation into the patterns of sirkulasi over the years also prefigured the nature of the macet to come.

First and most critically, the Suharto regime established intimate, but narrowly economic, linkages with Indonesia's embryonic business class, based not on circulation within the state but rather the private accumulation of capital. Dutch colonial policies

10 Adam Schwarz, A Nation in Waiting: Indonesia in the 1990s (Sydney: Allen and Unwin, 1994), pp. 133161. 
had discouraged indigenous entrepreneurship and trade, 11 spawned immigrant "Chinese" commercial networks,"12 and segregated and stigmatized this ethnic minority as "foreign," 13 thus creating a post-independence business class which was both overwhelmingly ethnic "Chinese" and politically very vulnerable. Playing on fears and resentments drummed up in the anti-communist pogroms of 1965-66, the Suharto regime exaggerated and demonized ethnic-Chinese links to Beijing and imposed draconian social restrictions on the ethnic-Chinese community as a whole. ${ }^{14}$

Meanwhile, in the business realm, the regime relied heavily on ethnic-Chinese pariah entrepreneurs to oil the rusty cogs of the state machinery and domestic market. Economic liberalization in the late 1960 s and oil boom in the 1970 s created unprecedented opportunities for capital accumulation under a state-led program of (mostly import-substitution) industrialization, with old patterns of Army "parallel financing" and business partnerships with ethnic-Chinese cronies persisting at the local level and now extrapolated to the national arena as well. Thus, as noted above, men like Liem Sioe Liong and Bob Hasan, ethnic-Chinese business partners of Suharto since the 1950s, began to construct vast diversified economic empires in the first two decades of the New Order, through state bank loans, monopoly franchise concessions, and other special government facilities. ${ }^{15}$ Other well-connected ethnic-Chinese konglomerat similarly emerged and thrived through partnerships with key military commands and sub-contracting deals with state enterprises. ${ }^{16}$ As massive flows of foreign investment spurred rapid export-oriented industrial growth and urbanization in the 1980s and 1990s, "konglomerat lokal" likewise emerged, invariably through collusive relationships with local military and civil officials in many cities and towns scattered throughout the archipelago. ${ }^{17}$ Yet their steady advancement was largely confined to capital accumulation in only the narrowest sense: New Order policies discriminating against the ethnic-Chinese impeded their circulation and ascendancy within the military hierarchy, the bureaucracy, or other circuitries of state power.

\footnotetext{
11 See Jennifer Alexander and Paul Alexander, "Protecting Peasants from Capitalism: The Subordination of Javanese Traders by the Colonial State," Comparative Studies in Society and History 33,2 (April 1991): 370394.

12 Onghokham, "Chinese Capitalism in Dutch Java," Southeast Asian Studies 27,2 (September 1989): 156176; James Rush, Opium To Java: Revenue Farming and Chinese Enterprise in Colonial Indonesia, 1860-1910 (Ithaca: Cornell University Press, 1990).

13 G. William Skinner, "The Chinese Minority," in Indonesia, ed. Ruth McVey (New Haven: Human Relations Area Files, 1963), pp. 97-117.

14 Charles A. Coppel, Indonesian Chinese in Crisis (Kuala Lumpur: Oxford University Press, 1983), pp. 5268, 99-176; Mély G. Tan, "The Social and Cultural Dimensions of the Role of Ethnic Chinese in Indonesian Society," Indonesia 1991 (Special Issue on the Role of the Indonesian Chinese in Shaping Modern Indonesian Life): 113-125.

15 See Jamie Mackie, "Towkays and Tycoons: The Chinese in Indonesian Economic Life in the 1920s and 1980s," Indonesia 1991 (Special Issue on the Role of the Indonesian Chinese in Shaping Modern Indonesian Life): 83-96.

16 See Harold Crouch, The Army and Politics in Indonesia (Ithaca: Cornell University Press, 1980), pp. 273303.

17 See Benny Subianto, "Portret Konglomerat Lokal," in Huru-Hara Rengasdengklok (Jakarta: Institut Studi Arus Informasi, 1997), pp. 89-108.
} 
Secondly, the regime also incorporated remnants of the local aristocracies which had supported the colonial state under the Dutch and survived and prospered in the post-independence era as the conservative backbone of Soekarno's PNI (Partai Nasionalis Indonesia) in many parts of the archipelago. In Java and Madura in the late 1960s and through much of the 1970s, the priyayi still retained numerous bupatiships and, at least in the case of Mohammad Noer, the governor's seat in East Java. ${ }^{18}$ The role of the Sultan Hamengku Buwono IX of Yogyakarta during this early period-first in the Cabinet and later as Suharto's Vice-President-symbolized the apogee of this trend. In the Outer Islands, a similar pattern prevailed, with Golkar typically built upon the bases of local aristocratic privilege and patronage networks previously sheltered beneath the umbrella of Soekarno's PNI. Yet by the late 1970s, the centralizing tendencies of the regime, as well as the overabundance of retiring military officers to fill bupatiships, provincial governor's seats, and national-level bureaucratic posts, spelled the limits of local aristocratic entrenchment, ascendancy, and accumulation in the New Order. ${ }^{19}$ Indeed, as with "Chinese" business networks, the Suharto regime imposed a definite ceiling on the accumulation of social and political capital through private family networks, with only one obvious major exception.

Thirdly, and by way of contrast, the Suharto regime provided ample opportunities for the entrenchment and advancement, through state and para-statal circuitries, of Indonesia's small, urban, Westernized intelligentsia and professional classes, which, due to colonial legacies, were disproportionately Christian in their faith and educational background. Early Portuguese influences in eastern Indonesia and later Dutch missionary efforts throughout the archipelago had created sizeable pockets of Catholics and Protestants, and together with the largely non-Muslim ethnic-Chinese minority, these Christians were, by the early twentieth century, conspicuously overrepresented in the ranks of the small but growing urban middle class of traders, professionals, and civil servants. By the time of independence this small Christian minority-thanks to early exposure to the urban cash economy (e.g. in the ethnic Chinese case), privileged access to Western-style education (e.g. missionary schools), and discriminatory state policies (e.g. in recruitment to the colonial army)-enjoyed a privileged position in business, the state bureaucracy (including the Army), and the urban social élite. ${ }^{20}$

Against this backdrop, Christian elements of the urban middle class were to forge close linkages with the embryonic Suharto regime in the late 1960s and early 1970s. University lecturers and student activists affiliated with the Partai Katolik and other Christian groups joined the rallies against the PKI and Soekarno in the critical first months of the New Order, and enjoyed something of a hegemonic position as the regime's leading political operatives for years to come. Most notoriously, General Ali Moertopo, close Suharto associate, political fixer, and head of Opsus (Special Operations), cultivated relations with a cluster of (ethnic-Chinese) Catholic activists

\footnotetext{
18 Hotman M. Siahaan and Tjahjo Purnomo W., Pamong Mengabdi Desa: Biografi Mohammad Noer (Surabaya: Yayasan Keluarga Bhakti dan Surabaya Post, 1997).

19 Burhan Djabier Magenda, "The Surviving Aristocracy in Indonesia: Politics in Three Provinces of the Outer Islands" (PhD dissertation, Cornell University, 1989).

${ }^{20}$ On the close linkage between Christianity and education in Indonesia, see Gavin W. Jones, "Religion and Education in Indonesia," Indonesia 22 (October 1976): 19-56.
} 
168 John T. Sidel

like Harry Tjan Silalahi and the brothers Yusuf and Sofyan Wanandi (Liem Bian Kie and Liem Bian Koen) who, with Moertopo's blessings, founded the Center for Strategic and International Studies (CSIS) in the early 1970s. This clique of "political technocrats" helped craft the defusion of Konfrontasi, draft the blueprint for ASEAN, build up Golkar and mastermind its first electoral success in 1971, and put an internationally palatable "spin" on the invasion of East Timor in 1975. ${ }^{21}$

Besides this tight-knit clique of Catholic activists and operatives, a somewhat broader pool of intellectuals associated with the Partai Sosialis Indonesia (PSI) claimed small pockets of influence within the regime. ${ }^{22}$ Best known since the 1950 s as the party of Westernized (and often Dutch-speaking), secularized "administrators" and urban professionals, the PSI had never commanded much in the way of a popular electoral base (and was banned in 1960 for its role in the CIA-backed regional rebellions of 195759), but its leading members and their ideas and broader sensibility long held a position of privilege and respect in the higher echelons of the bureaucracy, among the top leadership of the Army, on university campuses, and in the press. ${ }^{23}$ Crucially, PSI leaders enjoyed considerable credibility and close contacts among the regime's international backers, especially the US government. With prominent aristocrats and modernist Moslems among its leaders and sympathizers, the more loosely structured PSI network also had a potentially broader purchase than the more exclusivist (and secretive) Catholic jaringan centered in the CSIS. These PSI strengths were well recognized by Suharto in the fragile first years of the New Order, as suggested by early appointments such as that of PSI luminary and respected economist Professor Soemitro Djojohadikusumo as Trade and Industry Minister in 1968. ${ }^{24}$

Yet in the byzantine politics of Jakarta in the 1970s and 1980s, PSI-linked networks were relegated to semi-outsider status and viewed as potentially more oppositional than their Catholic rivals based in the CSIS. ${ }^{25}$ PSI leaders were closely linked with the "New Order radicals" of the Army's (West Java) Siliwangi Division, who were soon marginalized in favor of Suharto and his (Central Java) Diponegoro Division cronies. PSI associates and sympathizers were also among those blamed for the so-called Malari riots of January 1974, which precipitated the downfall of the avowedly "professional" security chief General Soemitro, a bitter rival of Ali Moertopo and his CSIS operatives. ${ }^{26}$

21 Richard Tanter, "Intelligence Agencies and Third World Militarization: A Case Study of Indonesia, 1966-1989" (PhD dissertation, Monash University, 1991), pp. 321-325, 430-432.

22 Donald Hindley, "Alirans and the Fall of the Old Order," Indonesia 9 (April 1970): 23-66.

${ }^{23}$ Herbert Feith, The Decline of Constitutional Democracy in Indonesia (Ithaca: Cornell University Press, 1962), pp. 129-131; Rudolf Mrázek, Sjahrir: Politics and Exile in Indonesia (Ithaca: Cornell University Southeast Asia Program, 1994), pp. 403-457.

24 See Subroto, "Recollections of My Career," Bulletin of Indonesian Economic Studies 34, 2 (August 1998): 67-92, especially pp. 70-76.

25 See the exhaustive account in François Raillon, Les étudiants indonésiens et l'Ordre Nouveau: Politique et idéologie du Mahasiswa Indonesia (1966-1974) (Paris: Editions de la Maison des sciences de l'homme, 1984).

26 See, for example, the highly tendentious account of PSI history and activities in Marzuki Arifin S.E., Fakta, Analisa Lengkap dan Latar Belakang Peristiwa 15 Januari 1974 (Jakarta: Publishing House Indonesia, 1974), especially pp. 21-75. 
Subsequent years still saw a handful of "technocratic" and PSI-ish Soemitro protégés, most notably Environment Minister Emil Salim, occupying Cabinet posts, but the ascendancy and long entrenchment of the Catholic General Benny Murdani as security and intelligence czar in the 1980 s maintained the upper hand for CSIS. The two rival networks reached something of a stand-off and modus vivendi in Golkar, the DPR, and the Cabinet, on elite university campuses, and in the media, where the Catholic-run Kompas evolved into Jakarta's newspaper of record and the PSI-ish magazine Tempo became the nation's most respected weekly. Feeding the growing circulation of such publications, the steady flow of students through the nation's top universities over the years reproduced the social base and source of recruitment for these two rival networks as they orbited within the upper echelons of civilian power in the regime.

Finally, and perhaps most problematically, the country's historically strong and autonomous networks of Islamic worship, education, and political organization were most weakly integrated into the power structures of the New Order. Unlike the British in Malaya, for example, the Dutch had by and large allowed Islamic schools, places of worship, scholars, and preachers to remain outside the control of the indigenous aristocracy and the emerging bureaucratic state. Against this backdrop, a variety of autonomous Islamic associations had emerged in the course of the early twentieth century, most notably the largely urban and self-consciously "modernist" Muhammadiyah (established in 1912) and the more rural-based and "traditionalist" Nahdlatul Ulama or NU (founded in 1926). ${ }^{27}$ These two powerful Islamic associations, first drawn into openly "political" activities by the Japanese authorities during the Occupation, served as the bases for many local anti-Dutch forces during the Revolution and later for two major political parties (Masjumi and NU) in the Soekarno era. ${ }^{28}$

Based in local institutions of Islamic worship and learning like the traditionalist pesantren (school of Koranic studies) and the modernist madrasah (Islamic school), these historically autonomous and socially embedded Moslem networks were marginalized and alienated by the militarizing, centralizing, and Westernizing tendencies of the Suharto regime in the $1970 \mathrm{~s}$ and $1980 \mathrm{~s} .{ }^{29} \mathrm{NU}$ party leaders played a crucial role in the student protests and pseudo-parliamentary maneuvers that led to Soekarno's downfall in 1966, and NU activists in regions like East Java provided the shock troops for the massacres of PKI members and sympathizers, but by the early 1970s the association was openly at odds with the Suharto regime. ${ }^{30}$ The 1971 election saw NU competing

27 Deliar Noer, "The Rise and Development of the Modernist Muslim Movement during the Dutch Colonial Period (1900-1942)" (PhD dissertation, Cornell University, 1963); Choirul Anam, Pertumbuhan dan Perkembangan Nahdlatul Ulama (Solo: Jatayu Sala, 1985).

28 See Harry J. Benda, The Crescent and the Rising Sun: Indonesian Islam Under the Japanese Occupation 19421945 (The Hague and Bandung: W. van Hoeve, 1958).

29 The (mostly NU-affiliated) pesantren, moreover, were not only rural-based but also run by kyai who, perhaps somewhat like the PNI-affiliated Javanese priyayi and Outer Island aristocrats, were enmeshed in local family networks and bonds of intermarriage with other kyai dynasties. On this minor (but rather critical) point, see Zamakhsyari Dhofier, "Kinship and Marriage Among the Javanese Kyai," Indonesia 29 (April 1980): 47-58.

30 See Andrée Feillard, Islam et Armée Dans L'Indonésie Contemporaine (Paris: L'Harmattan, 1995), pp. 63138; Agus Sunyoto, Banser Berjihad Menumpas PKI (Tulungagung: Pesulukan Thoriqoh Agung, 1996); 
170 John T. Sidel

intensely with the regime's political machine Golkar for votes in strongholds like East Java. ${ }^{31}$ Subsequent years saw the loss of NU control over the Ministry of Religion and the association's forced fusion with other Moslem groups into a single political party, the United Development Party (Partai Persatuan Pembangunan or PPP), which was subjected to heavy-handed government restrictions. ${ }^{32}$

Activists from the Muhammadiyah-linked student group HMI (Himpunan Mahasiswa Islam, Islamic Students' Association) had also joined in the anti-PKI rallies and anti-Soekarno maneuvers of 1965-66, but they and other modernist Muslim leaders were to be deeply disappointed by their exclusion from the regime in subsequent years. The modernist party Masjumi, banned since 1960 for its role in the regional rebellions, was prevented from regrouping and competing in the 1971 polls, and modernist Moslem leaders were forced to join with their traditionalist NU counterparts in the PPP in subsequent electoral contests. ${ }^{33}$ Masjumi activists were among those blamed for the Malari riots of January 1974,34 and intelligence operations masterminded in subsequent years by CSIS patron Ali Moertopo and later by the Catholic intelligence and security chief General Benny Murdani worked both to discredit certain modernist Moslem groups as fanatics and terrorists and to justify their harsh repression. ${ }^{35}$ With abangan (nominal) Moslems and Christians occupying a hegemonic position in the Palace, the Armed Forces, the Cabinet, Golkar, and the DPR in the 1970s and 1980s, many devout Moslems understandably saw themselves as unfairly excluded from the corridors of power. Hence the impressive showing of the PPP in Jakarta and a few other regions of the country in the elections of 1977 and 1982.

But meanwhile state policies and social trends over the three decades of the Suharto era worked gradually to propel new generations of devout Moslems socially "upwards" and into the orbit of the New Order state. The anti-communist hysteria of the early Suharto years, for example, drove millions of Indonesians to seek refuge in religious identity, institutions, and faith in the mid-late 1960s, including millions of Moslems of previously more abangan orientation. New government regulations requiring all citizens to declare their faith, expanding religion classes in state schools, and impeding inter-faith marriages strengthened the public markers and boundaries of Moslem identity. ${ }^{36}$

Over the thirty-two years of the New Order, moreover, the system of Islamic education in Indonesia grew considerably. Even traditional, rural boarding schools (pesantren) evolved in the direction of the modernist, more Western-style madrasah, and

Hermawan Sulistyo, "The Forgotten Years: The Missing History of Indonesia's Mass Slaughter (JombangKediri, 1965-1966)" (PhD dissertation, Arizona State University, 1997).

31 Ken Ward, The 1971 Election in Indonesia: An East Java Case Study (Clayton, Victoria: Monash Papers on Southeast Asia, 1974), especially pp. 90-113, 157-178.

32 Feillard, Islam et Armée, pp. 125-127, 143-156.

33 Muhammad Kamal Hassan, Muslim Intellectual Responses to "New Order" Modernization in Indonesia (Kuala Lumpur: Dewan Bahasa dan Pustaka Kementerian Pelajaran Malaysia, 1980), pp. 78-141.

34 Arifin, Fakta, pp. 21-75.

35 On the repression of Islamic activists and organizations in the 1980s, see Human Rights Watch, Human Rights in Indonesia and East Timor (New York: Human Rights Watch, 1989), pp. 76-85.

36 On these trends, see Robert W. Hefner, "Islamizing Java? Religion and Politics in Rural East Java," Journal of Asian Studies 46,3 (August 1987): 533-554. 
Islamic colleges like local Universitas Muhammadiyah and the branches of the staterun IAIN (Institut Agama Islam Negara or State Islamic Institute) expanded steadily in tandem with rapid urbanization and economic growth. ${ }^{37}$ Thus by the early 1990s, the rising number of Indonesians schooled under a distinctly, self-consciously "Islamic" rubric had become a visible feature of urban society in many parts of the archipelago. The public sphere of modern, urban middle-class life, for the very first time in Indonesian history, was now also claimed by those who defined themselves as pious Moslems. ${ }^{38}$

At the same time, this sociological sea change also swept rising numbers ofmostly "modernist" - devout Moslems into the nation's top élite universities and, by the late 1980s, into circulation within the corridors of the regime and its para-statal subsidiaries. HMI student leaders from élite schools like Yogyakarta's Universitas Gadjah Mada (UGM), Bandung's Institut Teknologi Bandung (ITB), and Jakarta's Universitas Indonesia (UI) were recruited in record numbers into the bureaucracy, the business world, and Golkar, as suggested by the rise of men like Mar'ie Muhammad, Ridwan Saidi, Adi Sasono, and Akbar Tanjung during this period. Within the Armed Forces, parallel trends were also visible with the ascendancy of devout Moslem officers such as General Try Sutrisno to top leadership positions in the late 1980s and early 1990s.

Against this backdrop, and in the context of the Catholic security czar General Benny Murdani's fall from power, the last ten years of the New Order saw President Suharto make assiduous efforts to incorporate the country's Islamic networks into the circuitries of regime power. As is well known, the President and countless other government officials made the pilgrimage to Mecca and began to signal in myriad other ways that the Islamic faith enjoyed a privileged position in Indonesian public life. In 1990, moreover, Suharto gave his blessings to the founding of ICMI, the Ikatan Cendekiawan Muslim se-Indonesia (Association of Indonesian Islamic Intellectuals), led by his long-time close associate and Minister for Research and Technology, Prof. Dr. Ir. B. J. Habibie.

In ICMI and the multistranded patronage empire of Habibie, modernist Moslems had gained, for the very first time, a jaringan of their own along the innermost corridors of power. Since the late 1970s, Suharto had promoted the establishment of a vast military-industrial complex under Habibie's aegis. As Minister of Research and Technology, Habibie controlled a sprawling empire of ten state-owned enterprises grouped under the Coordinating Agency for Strategic Industries, most notably Krakatau Steel, shipbuilder PT PAL, and aircraft producer IPTN. In a country where the predominance of a "pariah" ethnic-Chinese business class, the legacies of Revolusi, and the luxury of oil revenues legitimated an étatiste industrialization strategy, Habibie built up an enormous state-based patronage empire outside military and

37 Sidney Jones, "The Javanese Pesantren: Between Elite and Peasantry," in Reshaping Local Worlds: Formal Education and Cultural Change in Rural Southeast Asia, ed. Charles F. Keyes (New Haven: Yale University Southeast Asia Studies Monograph Series, 1991), pp. 19-41; M. Dawan Rahardjo, "The Kyai, the Pesantren and the Village: A Preliminary Sketch," Prisma I, 1 (May 1975): 32-43; and Feillard, Islam et Armée, pp. 225237.

${ }^{38}$ For signs of this trend, see, for example, the set of articles on "Boom Dai" in Tempo, April 11, 1992, pp. 13-23. 
technocrat control in the name of high-tech economic nationalism. Through his hold over "strategic industries" and responsibility for infrastructure projects and industrial development schemes, Habibie wielded considerable discretion over government personnel and contracts and built up an enormous clientele-mostly of urban, modernist, university-educated pribumi ("indigenous") Moslems-within the state and in private business circles. ${ }^{39}$

With the founding of ICMI in 1990, moreover, Habibie also created a new rubric for the patronage and cooptation of Islamic institutions, from mosques and schools to publishing ventures, think-tank activities and dakwah (preaching) groups. From its inception, ICMI and its leaders used these impressive resources to attract activists from a variety of Islamic associations and to broaden its influence in the state and deepen its reach within society. ${ }^{40}$ Over the 1990 s, Suharto engineered the elevation of Habibie to the governing body of Golkar, various Habibie protégés to key Cabinet positions, and a close Habibie associate, General Feisal Tanjung, as Commander-in-Chief of the Armed Forces. ${ }^{41}$

Meanwhile, a steady process of ICMI-isasi moved forward in Golkar, in the awarding of state contracts, on many university campuses, and beyond, in tandem with so-called de-Benny-isasi. An ICMI-affiliated think-tank, CIDES (Center for Information and Development Studies), soon began to compete with the Catholic CSIS, and its daily newspaper Republika tried (less successfully) to rival the Catholic-owned Kompas. ICMI support and influence soon extended to Islamic publishers, preachers, and pilgrims, into pesantren, madrasah, and IAIN, and to figures within both NU and Muhammadiyah. With Habibie at its helm, ICMI incorporated an expanding jaringan of Moslem professionals and "professional Moslems" into the circuitries of the regime. ${ }^{42}$

Yet both the limitations and the dangers of this pattern of social incorporation were soon visible within the corridors of state power in Jakarta and in Indonesian society at large. For if the logic of sirkulasi propelled new generations of triumphant "modernist" Moslem arrivistes upward and into the upper echelons of the regime, the accumulation of wealth and self-perpetuation in power by the President and his family imposed a ceiling on any further ICMI-ish ambitions for the foreseeable future. Suharto children, after all, had also won seats on the governing board of Golkar and begun to lobby for their own minions and allies in the Parliament, the Armed Forces, and the Cabinet. Their huge conglomerates continued to capture the juiciest state contracts and

${ }^{39}$ On Habibie, see Takashi Shiraishi, "Rewiring the Indonesian State," in Making Indonesia: Essays on Modern Indonesia in Honor of George McT. Kahin, ed. Daniel S. Lev and Ruth McVey (Ithaca: Cornell Southeast Asia Program, 1996), pp. 164-179.

40 For two contrasting views of these trends, see Robert Hefner, "Islam, State, and Civil Society: ICMI and the Struggle for the Indonesian Middle Class," Indonesia 56 (October 1993): 1-37; and R. William Liddle, "The Islamic Tum in Indonesia: A Political Explanation," Journal of Asian Studies 55,3 (August 1996): 613634.

41 The Editors, "The Sixth Development Cabinet Announced March 17, 1993," Indonesia 55 (April 1993): 167-176.

42 See, for example, Darul Aqsha, Dick van der Meij, and Johan Hendrik Meuleman, Islam in Indonesia: A Survey of Events and Developments form 1988 to March 1993 (Jakarta: Indonesia-Netherlands Cooperation in Islamic Studies, 1995), pp. 263-276. 
monopoly concessions, as Tommy Suharto's 1996 "national car" project amply attested. So long as Suharto was President, his children would remain entrenched at the pinnacle of New Order power.

"Islam," moreover, would also remain an overly ambitious banner in a nation boasting the single largest Moslem population and the most popular nongovernmental Islamic organizations in the world. With their long histories, deep roots in society, and widely divergent theological, institutional, and sociological underpinnings, NU and Muhammadiyah could hardly be so easily captured - or their leaders coopted-by an ICMI-based network emanating from the state. In short, the considerable autonomy of associational life and the great plurality of views long found in the Indonesian Islamic community made the creation and enforcement of a hegemonic state-based "Islam" an ultimately unrealizable project. ${ }^{43}$

Indeed, the promise of a majoritarian "Islam" as a rubric for the social advancement of millions of Indonesian Moslems ran up against the reality of a highly centralized and narrowly based pattern of elite circulation and capital accumulation under the Suharto regime. Year after year, thousands of Moslem youth left the nation's pesantren, madrasah, IAIN, and other schools and universities for the job market, only to find opportunities for civil service employment or upward social mobility in the private sector highly limited, even in the era of ICMI and expanding Islamic jaringan.44 As the Jakarta-based "Chinese" konglomerat and the Suharto children's business empires extended their reach throughout the archipelago with new factories and marketing networks, incorporating millions of Indonesians into new circuitries of production and consumption, popular resentment grew against the patterns of marginalization engendered by the very nature of New Order capitalism.

In this context, "Islam" in the 1990s was to provide not just new trappings for urban middle-class propriety, but an appealing idiom for a wave of mounting popular protest. By the 1980s, Indonesians in various parts of the archipelago, whether Moslem, Christian, or (as in Bali) Hindu, had begun to mobilize in countless local struggles against the increasing impingements of Jakarta-based konglomerat on community lands and livelihoods. Farmers fought vigorously against the conversion of their rice fields into dam projects, golf courses and factory belts, as did fishermen against the reclamation of shorelands, and urban slum residents against new evictions and construction. ${ }^{45}$ Small-scale traders and street vendors protested against the encroachments of department stores and shopping malls, ${ }^{46}$ and, despite heavy restrictions on union organizing and strikes, factory workers held work stoppages and other actions to raise wages and improve labor conditions. ${ }^{47}$ Even the planned bridge

43 On this key general point, see Eva-Lotta E. Hedman, "In Search of Oppositions: South East Asia in Focus," Government and Opposition 32,4 (Autumn 1997): 578-597.

44 See Chris Manning and P. N. Junankar, "Choosy Youth or Unwanted Youth? A Survey of Unemployment," Bulletin of Indonesian Economic Studies 34,1 (April 1998): 55-94.

45 See, for example, the fine study of the fiercely contested Kedungombo dam project in Central Java by Stanley, Seputar Kedung Ombo (Jakarta: Lembaga Studi dan Advokasi Masyarakat, 1994).

46 Ir. Herlianto, Urbanisasi, Pembangunan, dan Kerusuhan Kota (Bandung: Penerbit Alumni, 1997).

47 See Vedi R. Hadiz, Workers and the State in New Order Indonesia (London: Routledge, 1997); and Douglas Kammen, "A Time To Strike: Industrial Strikes and Changing Class Relations in New Order Indonesia" (PhD dissertation, Cornell University, 1997). 
174 John T. Sidel

between Surabaya and Madura foundered in the face of opposition from local Islamic leaders. ${ }^{48}$ By the early 1990 s, in cities and towns throughout Indonesia, local, popular manifestations of macet were clearly on the rise.

In short, the New Order regime incorporated a diverse set of social elites into its orbit through networks or jaringan. In the case of ethnic-Chinese businessmen, the linkages were based on narrow financial ties, with "pariah" status allowing for capital accumulation but impeding inclusion in the circuitries of state power. For "native" aristocrats like the Javanese priyayi, the logic of central state sirkulasi also imposed a definite ceiling on local family network penetration of the upper echelons of the New Order regime. Instead, the most important path for social networking and regime incorporation was located in the national system of modern tertiary education, in which a small minority of Christians and Westernized PSI-ish Moslems entrenched themselves in the early New Order years, but through which new jaringan of (mostly "modernist") devout Moslems were triumphant late-comers by the late 1980 s and early 1990s.

This pattern of jaringan-based incorporation into the power circuitries of the Suharto regime thus reproduced and reshaped existing social networks in Indonesian politics, through steady streams of students recruited via the nation's top universities into the New Order power élite. Such a pattern of sirkulasi was perhaps inevitable under such a conservative, bureaucratized form of authoritarian rule and in a society with a "pariah" business class engaged in capital accumulation but long excluded from the circuitries of state power. It also prefigured the nature and consequences of the macet to come.

\section{Countdown to Macet: 1988-1997}

Indeed, the final decade of the Suharto era witnessed an acceleration in capital flows and circulation within the state, but also the emergence and attempted management of incipient macet. Beginning in the late 1980s, the dismissal of long-time Armed Forces chief and intelligence czar General Benny Murdani and the abovementioned elevation of civilians to new heights of influence in the regime inspired disaffected elements in the military establishment to promote oppositional forces and activities against the President and the cluster of private interests linked to the Palace.

With Murdani remaining as Defense Minister (1988-93) and his countless protégés still entrenched in various key military and civilian circuitries within the regime, Catholic and PSI-ish jaringan soon mobilized into action, championing the causes of the urban middle and working classes that had grown so rapidly over the years and remained so weakly incorporated into the orbit of Suharto's New Order. Thus, journalists and parliamentarians received encouragement and assistance in exposés of government corruption and criticisms of government policies. Student groups, nongovernmental organizations, human rights groups, and even labor unions enjoyed a measure of tolerance (and in some cases, backing) previously withheld. ${ }^{49}$ Leaders of

48 Muthmainnah, Jembatan Suramadu: Respon Ulama terhadap Industrialisasi (Yogyakarta: LKPSM, 1998).

49 Edward Aspinall, "Students and the Military: Regime Friction and Civilian Dissent in the Late Suharto Period," Indonesia 59 (April 1995): 21-44. 
mass organizations once firmly subordinated to the New Order hierarchy began to display new-found independence, most notably Abdurrahman Wahid (popularly known as Gus Dur) of Nahdlatul Ulama (NU), who refused to join or support ICMI, and Megawati Soekarnoputri (daughter of Indonesia's first president), who, with the blessings of certain high-ranking Army officers, assumed the leadership of the Partai Demokrasi Indonesia (PDI) in 1993.50

Meanwhile, Murdani-linked military elements also began to apply pressure for sirkulasi in the innermost corridors of power in Jakarta. In 1988, a sudden interupsi by one Armed Forces' representative in the MPR expressed military opposition to the selection of former Golkar chief Sudharmono as vice-president, an unprecedented display of internal dissent. Five years later, in 1993, military delegates in the MPR went even further, forcing Suharto's hand by announcing the Armed Forces' choice for the vice-presidency: General Try Sutrisno, the outgoing Armed Forces Commander. The military establishment had begun to prepare-and to push-for sirkulasi at the hub of New Order state power.

Finally, in 1994, against the backdrop of these ominous developments, President Suharto began to undertake a dramatic crackdown on oppositional forces inside and outside the regime and to engineer a major consolidation of his personal authority. Major publications like the PSI-ish weekly Tempo were closed down, errant journalists were blacklisted, and censorship was intensified. Outspoken regime critics in the national press, the parliament, and the universities were bought off or bullied into silence. Labor leaders, student activists, and human rights lawyers came to face harassment and imprisonment for activities branded as subversive and reminiscent of the defunct Communist Party (PKI). Public figures like NU's Gus Dur found themselves virtually under siege, as regime-backed interlopers and intrigues worked to undermine their leadership of mass organizations. 51

Meanwhile, a purge of the Armed Forces ranks and a series of promotions removed suspected Murdani loyalists and other officers deemed insufficiently "reliable" from key posts and installed Palace favorites in their stead. General Hartono, an officer known for his deep involvement in the ongoing crackdown and his close relations with the President's favorite daughter, was installed as the Army Chief of Staff, while General Feisal Tanjung, an ICMI supporter and associate of Minister Habibie, was entrenched as Armed Forces Commander. Meanwhile, several other presidential favorites, most notably son-in-law Maj. Gen. Prabowo Subianto, received promotions to key garrisons in Jakarta. ${ }^{52}$

This cleansing of the regime's core arteries coincided with the clearing of unwanted pedestrians and political "traffic violators" from all major city streets. The culmination of this crackdown and consolidation came in July 1996, as security forces stormed the Jakarta headquarters of the PDI to enforce the ouster of popular leader Megawati from the party leadership. When crowds "rioted" in Central Jakarta in protest, hundreds

50 See, inter alia, Schwarz, A Nation in Waiting, pp. 230-263.

51 An early, but excellent, account of these developments is provided in The Limits to Openness: Human Rights in Indonesia and East Timor (New York: Human Rights Watch/Asia, 1994).

52 The Editors, "Current Data on the Indonesian Military Elite: September 1, 1993 - September 30, 1995," Indonesia 60 (October 1995): 101-146. 
176 John T. Sidel

were detained and arrested, including prominent labor leader Mochtar Pakpahan, and the event was (implausibly) blamed on a militant student and NGO activist group, the Partai Rakyat Demokrasi (People's Democratic Party or PRD). 53

This government crackdown effectively relegated to the sidelines those networks least incorporated into New Order avenues of élite circulation and capital accumulation but most capable of creating popular forms of macet in the streets. PRD leaders were detained and condemned to long jail sentences, and other student and NGO activists faced intensified repression and surveillance. SBSI (Serikat Buruh Sejahtera Indonesia, Indonesian Prosperous Workers' Union), the labor federation led by the now jailed Mochtar Pakpahan, suffered similar restrictions on its organizing efforts. The ousted PDI leader Megawati found her various legal attempts to achieve reinstatement effectively thwarted by the courts, ${ }^{54}$ and close ally Gus Dur began to distance himself from her cause and to adopt a more conciliatory stance towards the regime. This defensive posture was adopted in the face of renewed government efforts to oust Gus Dur from the NU leadership as well a broader campaign to discredit him and his organization. ${ }^{55}$

With the inner corridors of state power and the nation's city streets thus cleared of unwanted pedestrians, political "traffic violators" and other potential roadblocks, the Golkar machinery was revved up once again, to bulldoze its way to victory in the heavily restricted May 1997 elections and pave the road to Suharto's reanointment to the presidency by the MPR in March 1998. Yet a vigorous PPP campaign rallied thousands in the streets of many cities and towns, and local PPP branches staged unprecedented post-election protests in several towns in East Java which created embarrassing delays in the polling. More violence and trickery were clearly necessary to maintain the image of smooth circulation within the state in the face of incipient kemacetan politik on the ground.

In addition, Suharto's efforts to contain and silence dissenting voices within the military and civilian hierarchies of the regime had the effect of increasing his reliance on a narrowing circle of close family members and friends. Suharto's favorite daughter, Siti Hardijanti Rukmana or Mbak Tutut, played a prominent role in the election campaign and assumed a position of considerable power both as a member of the Golkar governing body and, since her mother's death in 1996, as one of her widowed father's most prominent advisors. ICMI chief B. J. Habibie also won greater prominence, along with a top Golkar post and rising speculation that he would be named to the vice presidency in 1998. Meanwhile, post-election rotations left Suharto son-in-law Maj. Gen. Prabowo Subianto in command of Kopassus (Special Forces), and a former presidential adjutant, General Wiranto, as Army Chief of Staff. Never before in New Order history had the uppermost echelons of the regime been captured by such a narrow cluster of Palace cronies, henchmen, and, crucially, relatives.

\footnotetext{
53 Gibran Ajidarma and Irawan Saptono, Peristiwa 27 Juli (Jakarta: Institut Studi Arus Informasi/Aliansi Jurnalis Independen, 1997); Agus Siswantoro, Dibalik Penyerbuan Kantor DPP-PDI: Dinegeri Sendiri Sakitpun Tak Boleh Menjerit (Jakarta: Upaya Warga Negara, 1996).

54 On the July 1996 attack on the PDI headquarters and its aftermath, see Ajidarma, Peristiwa 27 Juli.

55 See Greg Fealy, "The 1994 NU Congress and Aftermath: Abdurrahman Wahid, Suksesi and the Battle for Control of NU," in Nahdlatul Ulama, Traditional Islam and Modernity in Indonesia, ed. Greg Barton and Greg Fealy (Clayton: Monash Asia Institute, 1996), pp. 257-277.
} 
Meanwhile, this incipient clogging of the regime's core arteries only heightened pressures on the main pathways of social circulation. The onset of the crackdown in 1994 coincided with a precipitous increase in the frequency and intensity of antiChinese, anti-Christian, and other inter-ethnic violence. Over the next few years, crowds burned and looted "Chinese" shops and places of worship in towns and cities scattered across Indonesia, including Medan in 1994, Situbondo and Tasikmalaya in 1996, and Banjarmasin and Ujungpandang in 1997. In early 1997, clashes between Madurese and Dayaks in West Kalimantan led to the deaths of hundreds and the displacement of thousands of people in the area.56 Periodic church burnings, most notably in East Java, left more than three hundred Catholic and Protestant houses of worship in ashes. ${ }^{57}$ Sporadic anti-"Chinese" riots and church burnings had occurred in Indonesia in previous years, but never so often or so widely.

While the proximate causes of the riots varied from case to case, in virtually every instance a common set of circumstances provided a backdrop to the attacks on "Chinese" shops and places of worship. Firstly, in all cases, local residents clearly nursed resentment of the wealth, economic power, and social prominence enjoyed by ethnic-Chinese businessmen, with long-held accusations of "kolusi" with local authorities and simmering disputes over land, church construction permits, and residential arrangements heavy in the air. ${ }^{58}$ Moreover, in many cases, such sentiments were coupled with widely held grievances against the local authorities for various misdeeds, ranging from land evictions to imposition of an unpopular Golkar victory on a strongly pro-PPP community. In addition, well entrenched Islamic schools, like the pesantren in towns like Situbondo or the IAIN in cities like Ujungpandang, seemed to have socialized young Moslem men in a self-consciously Islamic atmosphere but not to guarantee adequate upward mobility in the form of well-paying jobs. In many cases, students from Islamic schools provided the "shock troops" of the riots. 59

Finally, in all cases, the stance of the local and national authorities seemed to encourage anti-"Chinese" violence. At the very least, police and military authorities tended to exercise considerable restraint in their reaction to anti-"Chinese" riots, whether out of fear of causing further violence, sympathy for the rioters, or more cynical reasons. ${ }^{60}$ In many instances, moreover, it was in reaction to local government decisions, like court rulings or police beatings, that angry mobs took to the streets, burning government buildings as well as "Chinese" shops.

\footnotetext{
56 Human Rights Watch/Asia, Indonesia: Communal Violence in West Kalimantan (New York: Human Rights Watch/Asia, 1997).

57 See Paul Tahalele and Thomas Santoso, eds., Beginikah Kemerdekaan Kita? (Surabaya: Forum Komunikasi Kristiani Surabaya-Indonesia, 1997).

58 See Perilaku Kekerasan Kolektif. Kondisi dan Pemicu (Yogyakarta: Pusat Penelitian Pembangunan Pedesaan dan Kawasan, Universitas Gadjah Mada, 1997).

59 Draft Laporan Suroai Peristiwa Situbondo 10 Oktober 1996 (Yogyakarta: Institut DIAN/Interfidei, 1997); Amuk Banjarmasin (Jakarta: Yayasan Lembaga Bantuan Hukum Indonesia, 1997); Huru-Hara Rengasdengklok (Jakarta: Institut Studi Arus Informasi, 1997); Amuk Makassar (Jakarta: Institut Studi Arus Informasi, 1998).

60 The Editors, "The Indonesian Military in the Mid-1990s: Political Maneuvering or Structural Change?," Indonesia 63 (April 1997): 104.
} 
178 John T. Sidel

In some cases, there were also suspicions that the riots had been instigated by elements within the regime. Similar rumors and accusations had arisen after the Malari riots in January 1974 and the disturbances in Solo and Semarang in late 1980, against the backdrop of mounting tension between rival factions in the Armed Forces. ${ }^{61}$ Some analysts had likewise attributed the series of events leading to the November 1991 Santa Cruz massacre in Dili, East Timor, to a plot by forces associated with Suharto son-in-law (then Col.) Prabowo Subianto to discredit and dislodge rival officers allied with (Ret.) General Benny Murdani. 62

In the case of the various anti-"Chinese" riots of 1994-97, by contrast, the evidence suggested something of a new pattern. Beyond theories linking the riots to local political squabbles, some reports provided evidence that the events in Situbondo and Tasikmalaya, for example, had been provoked or even staged to discredit and undermine Gus Dur by creating disturbances in well-known NU bailiwicks. In addition, these reports suggested, the riots were intended to embolden Indonesian Moslems to push for new gains in a larger struggle to overcome Chinese and Christian hegemony in the country's business and social life. Such reports implicated not only certain elements within the Armed Forces, but also Islamic activists associated with ICMI.63

If the pattern of sirkulasi within the regime had shifted to include a new élite Moslem jaringan, the diversion of macet into "riots" now facilitated the repression of those figures and networks most firmly located outside the regime and capable of mobilizing a mass base against it. The July 1996 upheaval in Jakarta had forced Megawati out of the 1997 elections, sidelined the leader of the country's largest independent union federation, and driven a budding network of militant student, labor, and NGO activists virtually underground. Gus Dur and his followers in NU suffered a similar fate after the Situbondo and Tasikmalaya riots several months later, as suggested by the imprisonment, torture, and in at least one instance death of local NU activists in these two towns, and by Gus Dur's much disparaged embrace of Mbak Tutut and Golkar during the election campaign in 1997.

Thus the decade leading up to the current economic crisis in Indonesia saw a confluence of discernible trends within the Suharto regime and in Indonesian society at large. The President succeeded in squashing oppositional forces by purging his regime of potentially disloyal elements, cracking down on dissent, and further entrenching close family members and cronies, against a backdrop of fluid capital flows and ongoing military mutasi. Yet this pattern of political involution threatened to undermine the logic of internal regime sirkulasi and to precipitate the onset of macet.

\footnotetext{
61 For contrasting interpretations along such lines with regard to the Malari riots, see Arifin, Fakta; "Siapa Dalang Peristiwa Malari?," Forum Keadilan, May 26, 1994, pp. 92-103; and Heru Cahyono, Pangkopkamtib Jenderal Soemitro dan Peristiwa 15 Januari '74 Jakarta: Pustaka Sinar Harapan, 1998). On the 1980 events in Central Java, see P. Bambang Siswoyo, Huru Hara Solo Semarang (Solo: Bhakti Pertiwi, 1981).

62 The Editors, "Current Data on the Indonesian Military Elite," Indonesia 53 (April 1992): 98-99.

63 See, for example, the articles on "Operasi Naga Hijau" in Forum Keadilan, February 10, 1997, pp. $12-21$. Two unpublished (but well publicized) reports by NU-affiliated authors, "Draft Laporan Penelitian Kerusuhan Tasikmalaya 1996" and "Draft Buku Putih Situbondo," offer ample empirical evidence to support such conclusions. Copies of these two reports have been obtained by the author, including two different versions of the latter paper.
} 
The congestion at the heart of the New Order, moreover, combined with rising circulatory pressures within society to provoke frequent episodes of macet, in the form of localized, surgically operable "anti-Chinese riots" which only diverted and disrupted the flow of popular energies against the pattern of predatory accumulation by the Suharto children's konglomerat and impending constriction of circulation within the regime. It was in this highly inauspicious context that 1997 drew to a close and an emerging world economic crisis began to unfold.

\section{January-April 1998: Kemacetan Kredit, Kemacetan Politik}

Kemacetan kredit had set in. As international investors and lenders suddenly started to abandon long-popular East Asian markets in the latter half of 1997, the Indonesian economy suffered most of all, with the rupiah depreciating 70 percent and the Jakarta stock exchange index falling 50 percent from mid-July 1997 to early January 1998. Indonesia's vulnerability to such rapid fluctuations in world currency markets reflected both extremely high levels of overseas borrowing (especially private, unhedged, short-term debt) as well as widespread perceptions (and self-fulfilling predictions) that rising cronyism and nepotism made the economy extremely weak in the face of a crisis. ${ }^{64}$

Indeed, the downward spiral of crisis began to accelerate quite precipitously at the end of the year, as uncertainties regarding the stability of the Suharto regime multiplied. In late October 1997, the government announced an austerity program worked out with the IMF and began to shut down several ailing local banks, but the rupiah continued to plummet. With the largely appointed People's Consultative Assembly due to meet in March 1998 to name the president and vice-president for the next five-year term, rumors were rife in Jakarta about Suharto's health, his choice of running-mate, and the implications for subsequent succession scenarios. ${ }^{65}$

As early as November 1997, moreover, it became clear that the ongoing trends sketched in the pages above had conditioned the Suharto regime to view and respond to the unfolding crisis in essentially political terms. Early that month the President's son Bambang Trihatmodjo had reacted angrily to the inclusion of his Bank Andromeda among the sixteen private banks targeted for government liquidation, initiating a lawsuit against the Cabinet officials responsible and speaking darkly of a conspiracy behind the decision. Significantly, the chief targets of his ire were Bank Indonesia Governor Soedradjad Djiwandono, son-in-law of PSI luminary Soemitro Djojohadikusumo and a Catholic with close links to CSIS, and widely respected Finance Minister Mar'ie Muhammad, former 1966 activist and leader of the modernist Moslem student group HMI, and a known foe of Habibie and his high-tech projects. These officials, Bambang Trihatmodjo's comments suggested, were part of a larger

\footnotetext{
64 International Monetary Fund, "Indonesia - Memorandum of Economic and Financial Policies," January $15,1998$.

65 On the unfolding economic crisis, see: Ross H. McLeod, "Postscript to the Survey of Recent Developments: On Causes and Cures for the Rupiah Crisis," Bulletin of Indonesian Economic Studies 33,3 (December 1997): 35-52; Hadi Soesastro and M. Chatib Basri, "Survey of Recent Developments," Bulletin of Indonesian Economic Studies, 34,1 (April 1998): 3-54.
} 
conspiracy to discredit his good name and that of his family. In a sense, of course, he was absolutely right. ${ }^{66}$

Events in December seemed to confirm the political nature of the crisis. In midmonth, Suharto, apparently suffering after a minor stroke, took ten days' rest from his official duties, heightening speculation about his health and the succession question. By the first week of January 1998, rumors had clearly spun out of control and with devastating effects, sending the rupiah to a previously unimaginable level of 10,000 to the US dollar and setting off runaway inflation. ${ }^{67} \mathrm{~A}$ wave of panic-buying ensued in markets, stores, and supermarkets in various parts of the archipelago. ${ }^{68}$

The government response to this much-publicized course of events was swift but double-edged. On the one hand, by January 15, President Suharto had signed a new agreement with the IMF, committing Indonesia on paper both to new austerity measures and a set of bank restructuring, deregulation, privatization, tax reform, and liberalization programs in exchange for US\$33 billion in new loans. As in previous periods of declining state revenues and private investment, the President now promised to open up new gateways into the circuitries of the economy, thus relieving the threat and build-up of macet.

On the other hand, this view of unfolding macet as propelled by political forces prevailed in the Palace, encouraging Suharto to adopt a tactic of staging new traffic diversions and disruptions. Top government officials, including Suharto, engaged in a series of maneuvers which served not only to undermine the supposedly confidenceinspiring effects of the IMF deal on global currency and equity markets, but also to create an atmosphere deeply hostile to the country's ethnic-Chinese business class and highly conducive to "anti-Chinese" riots. The diversion of macet, rather than the easing of sirkulasi, was the strategy of the regime.

A number of government steps and statements, for example, served to heighten many observers' skepticism about the Suharto government's commitment to the deal with the IMF. As photos of President Suharto signing the agreement under the stern gaze of IMF Director Michel Camdessus circulated in the domestic and foreign media, Suharto began to play the "nationalist" card. Habibie was floated as his likely choice for the vice-presidency, despite well-known skepticism in international business and financial circles with regard to Habibie's expensive and as yet largely unproductive high-tech projects. Although the markets reacted violently to this news, with the rupiah slipping as low as 17,000 to the U.S. dollar, Habibie was soon officially endorsed as the candidate of Golkar and subsequently "elected" in mid-March by the tightly controlled People's Consultative Assembly as Vice President, along with Suharto as President, for the five-year term of 1998-2003.

\footnotetext{
66 See, for example, "Bambang Tri Gugat Menkeu ke PTUN: Ini Menyangkut Kredibilitas Saya," Surabaya Post, November 4, 1997; "Bambang dan Probo PTUN-kan Pemerintah: Penutupan Bank Andromeda Sangat Ironis," Jawa Pos, November 4, 1997; "Langkah Misterius di Balik Likuidasi," Forum Keadilan, November 17, 1997; and “Di Balik Skenario Likuidasi 16 Bank," Infobank, November 1997, pp. 2-5.

67 "Inflasi Surabaya 21,21 persen," Surya, March 5, 1998.

68 See, for example, "Isu Kudeta, Pasar Diserbu," Surya, Januari 9, 1998, p. 1; and John McBeth, "Ground Zero," Far Eastern Economic Review, January 22, 1998, pp. 14-17.
} 
Meanwhile, in more specific policy terms, Suharto and other Cabinet officials began to issue statements suggesting moves that contradicted the agreement with the IMF. Expensive projects of an avowedly "nationalist" bent would be continued despite pledges of an end to government subsidies, and monopolies officially due for termination would survive in new form, it was implied.69 More generally, the President and several Cabinet ministers began to question in public whether the terms of the IMF agreement were consistent with the Indonesian Constitution and with Pancasila, the official state ideology. Finally, Suharto and his advisors floated a plan to adopt a "Currency Board System," which would peg the Indonesian rupiah at 5,500 to the US dollar and require the government to commit its dwindling foreign reserves to the defence of an extremely weak and apparently unreliable local currency. ${ }^{70}$

In tandem with these apparently "nationalist" moves in the realm of economic policy, the Suharto regime also launched an unprecedented attack on the ethnicChinese business community. Part of this attack focused on Sofyan Wanandi, a businessman of Chinese ancestry and Catholic faith who was known not only for his control over a diversified group of companies, the Gemala Group, but also his close ties to the CSIS, the conservative think-tank that represented certain "Chinese" / Catholic business interests and retired military officers such as (Ret. Gen.) Benny Murdani. ${ }^{71}$

Wanandi had openly voiced skepticism about the government's willingness to implement the terms of the IMF agreement, patently refused to join the governmentled "Cinta Rupiah" campaign, and reportedly expressed hopes that the vice president chosen for the 1998-2003 would be drawn from the Armed Forces. ${ }^{72}$ Rumors later circulating in Jakarta suggested that he had been lobbying for specific vice-presidential candidates-including incumbent Try Sutrisno and Army Chief of Staff General Wiranto-and that news of his views had angered and alarmed Suharto. ${ }^{73}$ In short, Wanandi represented a cluster of jaringan - Catholic, business, and military-seen as opposed to the Suharto regime's policies and to the vice-presidential candidacy of Habibie.

Against this backdrop, Sofyan Wanandi and his brother, CSIS board member Jusuf Wanandi, soon found themselves vulnerable to attack. On January 18, 1998, just three days after the signing of the IMF agreement, a bomb exploded in an apartment in Jakarta, leading to an investigation headed by Greater Jakarta Regional Military Commander Maj. Gen. Sjafrie Sjamsoeddin, a close ally of Maj. Gen. Prabowo, the President's son-in-law. The authorities subsequently blamed remnants of the PRD, the small leftish party scapegoated after the riots in July 1996, for the explosion but also claimed to have "discovered" documents linking PRD activists to the Wanandi brothers and CSIS. Through much of the month of February, front-page articles about

69 "Paket Reformasi IMF: Monopoli dan Kartel Jalan Terus?," D \& R, February 28, 1998, pp. 62-63.

70 On these developments, see, for example, John McBeth, "Double or Nothing," Far Eastern Economic Review, February 26, 1998, pp. 14-17.

71 "Mereka Bicara tentang Sofyan dll," $D \& R$, February 21, 1998, pp. 29-33.

72 See, for example, Wanandi's comments as quoted in "CSIS: Konglomerat bisa kabur," Surya, January 18, 1998, p. 1.

${ }^{73}$ See also “Kontroversi Sofyan Wanandi Setelah Ledakan," Forum Keadilan, February 23, 1998, pp. 12-21. 
182 John T. Sidel

the case were published in newspapers and magazines, demonstrations for the closure of CSIS were held by Islamic activists, and Sofyan Wanandi was brought in for repeated, lengthy interrogations by the authorities. ${ }^{74}$

News of the case faded and then disappeared entirely in early March as the People's Consultative Assembly convened and Suharto and Habibie were "elected" unanimously as President and Vice-President, respectively. If, as many analysts suspected, the campaign against Sofyan Wanandi and CSIS was at least partly intended to cow opponents to Habibie within business and military circles, then in these terms it could be deemed a success. Yet the attack on Sofyan Wanandi must also be seen against a broader pattern of government actions in January and February 1998, and with an eye to a wider set of consequences.

Indeed, in January and February 1998, ranking Indonesian government officials, including President Suharto, actively began to stoke popular resentments against ethnic Chinese businessmen in the country. Spokesmen for the Armed Forces, for example, issued statements revealing that then Armed Forces Commander General Feisal Tanjung had contacted thirteen of the nation's wealthiest ethnic-Chinese businessmen to demand that they join the "Cinta Rupiah" campaign and exchange their US dollars for Indonesian rupiah. ${ }^{75}$ Subsequent weeks saw mounting official attacks against unnamed currency speculators, described by the military's chief parliamentary representative as "traitors" and by President Suharto himself as part of a "conspiracy" to reduce the value of the rupiah to 20,000 to the US dollar. ${ }^{76}$ From the language used, it was abundantly clear to all who cared to read or listen that the President and his minions were referring not only to Sofyan Wanandi in particular but also to ethnic-Chinese businessmen in general.

In addition, top government officials, both civilian and military, actively encouraged Islamic groups to amplify and act upon these anti-Chinese sentiments. On the evening of January 23, 1998, for example, an estimated four thousand activists from several key Islamic groups joined three thousand Kopassus (Special Forces) troops for an unprecedented and much-publicized breaking of the Ramadan fast at the Kopassus headquarters in Jakarta. This occasion brought together then Kopassus Commander Maj. Gen. Prabowo Subianto, the President's son-in-law, with prominent leaders of Islamic groups such as Dewan Dakwah Islamiyah Indonesia (Indonesian Islamic Preaching Council), and KISDI, the Indonesian Committee for World Muslim Solidarity, both well known for their strident attacks on Christian and Chinese predominance in many spheres of Indonesian business and society. ${ }^{77}$

74 On this case, see, for example, the following magazine cover stories: "Bom untuk Konglomerat," $D \& R$, February 7, 1998, pp. 24-7; "Sofjan Wanandi dan CSIS," Gatra, February 14, 1998, pp. 23-32; "Dituduh Apa Lagi Sofyan Wanandi?," DER, February 14, 1998, pp. $20-21$.

75 See "Panglima ABRI Telepon 13 Konglomerat," Kompas, January 15, 1998, p. 1; “ABRI imbau nonpri jual dolar," Surya, January 15, 1998, p. 1.

76 "Syarwan: Mereka Penghkianat," Republika, January 24, 1998, p. 1; “'Ada Yang Sengaja Goyang Indonesia'," Jawa Pos, February 12, 1998, p. 1.

77 On these groups, see R. William Liddle, "Media Dakwah Scripturalism: One Form of Islamic Political Thought and Action in New Order Indonesia," in Toward a New Paradigm: Recent Developments in Indonesian Islamic Thought, ed. Mark R. Woodward (Tempe: Arizona State University Program for 
These groups, already inclined and mobilized to support ICMI chairman Habibie's vice-presidential candidacy and to attack CSIS and Sofyan Wanandi, undoubtedly felt further emboldened by Maj. Gen. Prabowo's generous display of support for their activities. In a variety of publications and public fora-including a mid-February KISDI rally before thousands of supporters at Jakarta's Al-Azhar Mosque ${ }^{78}$-calls were voiced for a struggle against "traitors" and "liars" like Wanandi and his ilk.79 Activists like Hussein Umar, Secretary General of Dewan Dakwah, set out across the country to spread the message beyond Jakarta.

Meanwhile, both national and local government officials made clear that the definition of "treason" to the Indonesian nation would be understood in religiously and ethnically colored terms. From its inception, the regime had spoken of a "krisis moneter" (krismon) rather than a "krisis ekonomi," suggesting that both the source of, and the solution to, the crisis lay in the mastery and manipulation of currency markets. In early February 1998, moreover, following a meeting with Suharto, the governmentcreated Majelis Ulama Indonesia (Indonesian Religious Scholars' Council) called for a jihad (holy war) against "speculators and hoarders," defined broadly enough to cover the thousands of-mostly ethnic Chinese-shopkeepers, merchants, and businessmen scattered across the archipelago. ${ }^{80}$

In cities and towns in Java and various other parts of the country, newspapers were soon awash with reports of local police and military officials investigating and punishing suspected "hoarders." 81 However this new crime was defined, it was clear, shopkeepers and merchants were now burdened with new "protection costs" on top of previous exactions and the rapidly rising cost of goods. In addition, as the falling rupiah and resultant inflation sent prices of essential commodities rocketing upwards, local authorities, from bupatis (regents) to regional military commanders, began to requisition amounts of the so-called "nine basic goods" for sale at specially organized distribution centers called pasar murah. 82 Many local Islamic groups soon launched parallel efforts, encouraging hopes about the possible role of pesantren and madrasah as distribution centers to replace the much disparaged "Chinese"-owned shops and marketing networks. 83

Southeast Asian Studies, 1996), pp. 323-355; and Robert W. Hefner, "Print Islam: Mass Media and Ideological Rivalries Among Indonesian Muslims," Indonesia 64 (October 1997): 77-103.

78 "Ketua Kisdi: Sofyan Wanandi Pengkhianat," Memorandum, February 9, 1998, p. 3.

79 See, for example, the various articles in Media Dakwah, February 1998, pp. 41-59.

80 On the MUI call for a jihad, see, for example, "Seruan Jihad untuk Siapa?," $D \& R$, February 21, 1998, pp. 72-73; Masdar F. Mas'udi, "Call for jihad 'may have caused riots'," Jakarta Post, February 20, 1998, p. 1; and Rosdiansyah, "Seruan jihad MUI penyebab kerusuhan?," Surya, March 5, 1998, p. 6.

81 See, for example, "Operasi Sembako, Dua Spekulan Diperiksa," Jawa Pos, January 16, 1998, p. 11; "Diperiksa, Tiga Gudang Penyimpanan Sembako," Jawa Pos, January 18, 1998, p. 12; "'Cari dan Temukan Para Penimbun'," Republika, February 15, 1998, p. 1; "Penimbun Sembako di Padang Resmi Jadi Tersangka," Republika, February 18, 1998, p. 5; "Pengusaha Giling Padi Trauma, Dituduh Menimbun," Kompas, February 21, 1998, p. 11; and "13 Penimbun Sembako Jadi Tersangka," Republika, Februar 24, 1998, p. 14.

82 See, for example, "Walikota Bangga, Warganya Gelar Pasar Murah Sembako," Surabaya Post, February 27, 1998, p. 5; "Bagi-bagi Sembako," Surabaya Post, February 28, 1998, p. 3.

83 "Ponpes Jatim Jadi Distributor Sembako," Republika, February 19, p. 5; "Pesantren, Distributor Sembako?," Jawa Pos, February 25, 1998, p. 4. 
184 John T. Sidel

In short, a wide variety of government statements and more concrete actions in the course of January and early February 1998 worked to create an atmosphere of public, officially-sanctioned suspicion and resentment not only towards national konglomerat like Sofyan Wanandi but also the thousands of ethnic-Chinese shopkeepers, merchants and businessmen scattered throughout the Indonesian archipelago. These steps were taken in a country whose government and majority population had long stigmatized the ethnic-Chinese minority as foreign and predatory, and shown considerable sympathy for heavy restraints on the unfettered operation of the so-called free market. These moves were made at a time when the most dramatic and broadly felt effects of the crisis-rapidly rising prices-were first being experienced directly via Chineseowned shops and stores throughout the country. Small wonder that many Indonesians thus saw local ethnic-Chinese shopkeepers as profiting, rather than suffering, from the crisis, as perpetrators rather than victims of the conspiracies and crimes referred to by Suharto and his minions. With newspaper articles reporting almost daily about police and military riot-simulation exercises in various parts of the country, the stage was set for macet diversion and disruption.

Indeed, against this inauspicious backdrop, the months of January and February 1998 saw a series of small-scale riots take place in a number of towns and cities around Indonesia, including Java, Sumatra, Sulawesi, Lombok, and Flores. In virtually all cases, the riots took the form of attacks on Chinese-owned shops or department stores, with looting and destruction of goods. ${ }^{84}$ In many cases, Catholic or Protestant churches were also targeted by the rioting crowds, leaving dozens of Christian houses of worship damaged, burned down, or entirely destroyed by mid-February according to one estimate at the time. ${ }^{85}$ Reports that some riots were started by outsiders who arrived in trucks or motorcycle convoys led some local and foreign journalists to conclude that many of these incidents had in fact been staged by elements within the regime. 86

While the riots did not lead to any mass killings or spread much beyond ephemeral, local episodes, they understandably helped to create (or at least exacerbate) a climate of growing fear and uncertainty. Small-town ethnic-Chinese shopkeepers closed their shops and maintained an especially low profile (even during the traditionally cacaphonous Chinese New Year), while many of their wealthier counterparts in the big cities reportedly purchased open airplane tickets for Singapore or Hong Kong.

Meanwhile, the dramatic and in some instances exaggerated coverage that the riots received in foreign media led to growing international worries regarding "social unrest" in Indonesia. ${ }^{87}$ Foreign governments issued statements of concern, dispatched

\footnotetext{
84 Indonesian newspapers and magazines featured hundreds of articles about the riots in January and February 1998. For an English-language summary, see Human Rights Watch, Indonesia Alert: Economic Crisis Leads to Scapegoating of Ethnic Chinese (New York: Human Rights Watch, 1998), especially pp. 8-15.

85 "The Number of Churches Closed, Destroyed, or Burnt Down Every Month in Period 1998" (Surabaya: ICCF, 1998).

86 John McBeth and Salil Tripathi, "Playing With Ire," Far Eastern Economic Review, March 5, 1998, pp. 1819.

87 See, for example, Michael Richardson, "U.S. Commander Sounds Alert on Indonesia Unrest," International Herald Tribune, February 7-8, 1998, pp. 1, 4.
} 
special envoys to see Suharto, and ordered their embassies to prepare emergency evacuation measures for their citizens on Indonesian soil. The IMF, facing a wave of criticism for its alleged mishandling of the crisis and mounting prospects of a deteriorating situation in Indonesia, began to signal its own recognition of the need to reevaluate and perhaps renegotiate the agreement signed in mid-January 1998.

Then, as the March 1998 session of the People's Consultative Assembly opened in Jakarta, the appearance of order was rapidly restored. The riots halted abruptly, and Suharto and Habibie were unanimously "elected" President and Vice-President, respectively, by the tightly controlled, mostly appointed assembly, without a single interupsi in the proceedings such as had occurred in 1988 and 1993. A wave of military reassignments saw Prabowo promoted to the command of Kostrad, the Army Strategic Reserve Command, and awarded the rank of Lieutenant General. Other key military rotations left such crucial positions as Army Chief of Staff and Greater Jakarta Regional Military Commander in the hands of close Prabowo associates and, in operational terms, seemingly weakly counterbalanced by the new Armed Forces Commander and Defence Minister, General Wiranto, and his allies in senior staff positions and other regional command posts.

In the realm of economic policy, moreover, Suharto likewise appeared to have won some decisive victories. Despite much-ballyhooed opposition from many quarters and the inauspicious timing of the crisis, he had succeeded in installing his close associate, ICMI chief and national high-tech czar Habibie as Vice President. His choices for the new Cabinet, moreover, tended to replace technocrats with close family friends and allies, like presidential golfing and business partner Mohammad 'Bob' Hasan (Suharto's first and only ethnic-Chinese Cabinet minister) as Minister for Trade and Industry, daughter Mbak Tutut as Minister for Social Affairs, and her long-rumored paramour (Ret.) General Hartono as Minister of Home Affairs. Such choices, especially that of Hasan and a Tutut ally as the new Minister of Finance, seemed to guarantee that Suharto family interests would not be unduly compromised by IMF-prescribed reforms. Meanwhile, by mid-April, Suharto had negotiated a new agreement with the IMF, one viewed by some analysts as considerably more "flexible" than the one signed almost three months earlier. ${ }^{88}$ With Habibie as Vice-President, family members and cronies in the Cabinet and Army leadership, and a fresh infusion of foreign capital on the way, Suharto's diversionary and disruptive tactics in the streets appeared to have overcome the challenge of macet in the corridors of state power.

\section{May 1998: Macet Total}

Yet such diversions and disruptions in the streets only delayed and deepened the process of macet total. The attacks on Sofyan Wanandi and CSIS, and on "hoarders and speculators" more broadly, could not but contribute to the circumstances which kept local and foreign businessmen alike from making new investments and other longoverdue decisions. The dynamics set in motion by these measures, moreover, including the riots, likewise further weakened the stability and value of the rupiah in

88 See, for example, John McBeth, "The Twilight Zone," Far Eastern Economic Review, April 16, 1998, pp. 1820. 
January and February, increasing the already enormous and unsustainable levels of foreign debt owed by local companies and the Indonesian government itself. Thus the new agreement signed with the IMF in mid-April 1998, while supposedly more "flexible" than the mid-January deal, was based on much more pessimistic forecasts: higher debt levels, higher inflation, and negative economic growth ( -4 percent) for the year rather than stagnation. The impact of these dramatically downward trends was now all too evident in rising unemployment, costs of living, scarcities, and hardships for millions of Indonesians. IMF disbursement of funds, moreover, was now conditional on monthly assessments of Indonesian progress on economic "reform." 89 No end to kemacetan kredit was in sight.

Meanwhile, the adventurist anti-"Chinese" scapegoating in January-February and the increasingly nepotistic personnel and policy decisions in March-April had begun to exacerbate the threat of impending kemacetan politik. The rapid ascendancy and multifarious activities of Lt. Gen. Prabowo and his allies had embittered avowedly more "professional" officers in the military establishment and rallied them around the respected new Armed Forces Commander and Defense Minister, General Wiranto, who had maintained a stoic, melancholy public silence in the preceding months, punctuated by his attack on the anti-"Chinese" campaign as "garbage." 90 The dismissal of regime "technocrats" like Soedrajad Djiwandono and Mar'ie Muhammad and their replacement with more pliable Suharto family flunkies had likewise dismayed many in PSI-ish, CSIS, and HMI circles and the chattering classes more broadly. Even ICMI activists were said to be bitterly disappointed that their own (well-publicized) wish-list of Cabinet ministers had mostly been scotched by the appointment of Mbak Tutut's favorites in March. The onset of kemacetan kredit had only exacerbated the problemsand accelerated the process-of kemacetan politik at the very hub of the regime.

With Sofyan Wanandi and the CSIS network on the defensive, it was now the turn of the old PSI jaringan to mobilize urban middle-class sentiment against the regime. In March, women from Universitas Indonesia (UI) and other élite circles, led by famed astronomer Professor Karlina Leksono, formed a group called "Suara Ibu Peduli" (Voice of Concerned Mothers) and protested outside government offices against the rising price of milk and other failings of the regime. ${ }^{91}$ More impressive, perhaps, was the former Environment Minister Emil Salim's self-proclaimed vice-presidential candidacy, the only open challenge to Habibie. While Salim's candidacy failed to stimulate an interupsi in the MPR in March, it did win vocal support from such PSI luminaries and fellow former cabinet ministers as Soemitro Djojohadikusumo, Mohammad Sadli, and Selo Soemardjan, as well as respected Islamic scholar Nurcholish Madjid. ${ }^{92}$ Knowledgeable observers suggested that Salim's vicepresidential bid enjoyed quiet sympathy in the upper ranks of the military

${ }^{89}$ International Monetary Fund, "Indonesia - Supplementary Memorandum of Economic and Financial Policies," April 10, 1998.

90 "Jangan Sebarkan Sentimen SARA," Kompas, February 10, 1998, p. 1; "KSAD Jenderal TNI Wiranto: Hasutan Pihak Tertentu Jadi Pemicu Kerusuhan," Republika, February 16, 1998, p. 1.

91 "Karlina Leksono: 'Kita Sudah Terlalu Lama Diam'," $D$ \& R, March 14, 1998, pp. $34-37$.

92 See "Sebuah Ikhtiar di Tengah Kemustahilan," $D \& R$, February 28, 1998, p. 20; and "Emil Salim: Ini Pertarungan Antar-Ide'," $D \& R$, February 28, 1998, pp. 21-23. 
establishment (where the PSI had long enjoyed influence) and broad support in middle-class circles.

Indeed, March and April 1998 saw the emergence and spread of anti-government student protests at college campuses in many parts of the archipelago, including the elite universities which long served as nodal points in recruitment for and reproduction of the New Order. By the end of April, moreover, growing evidence suggested that the students' demands for "Reformasi" now enjoyed solid legitimacy and support, both within the regime and among key constituencies in Indonesian society at large. ${ }^{93}$ PSI-ish university lecturers, deans, and rectors soon began to appear and speak out at campus rallies, and luminaries like Emil Salim and Selo Soemardjan voiced their support on such occasions and in newspaper columns. ${ }^{94}$ Retired generals soon joined their ranks.

Beyond these circles, moreover, elements of the emerging "modernist" Moslem jaringan also began to mobilize against the regime. Muhammadiyah leader (and UGM professor) Dr. Amien Rais had emerged as a vocal critic of Suharto in mid-1997, distanced himself from ICMI and, in the face of the anti-"Chinese" campaign of January-February 1998, adopted a strong stance against the government and its narrow sectarianism. By late April, he emerged at the forefront of the "Reformasi" campaign and enjoyed the support of a broad range of HMI, NU-linked, Catholic, and other student groups at university campuses around the country. ${ }^{95}$

In the face of student and jaringan mobilization, moreover, evidence of internal strain and discord within the regime soon began to surface. A few top government officials spoke darkly of vague conspiracies behind the student protests, while more and more figures in the Cabinet and the Parliament embraced the vague notion of "Reformasi" and the process of public "dialogue" with student leaders. In the military establishment, for example, Army Chief of Staff General Soebagyo, a pliant Prabowo ally, issued stern warnings, dismissive comments, and thinly veiled threats to the students as protests endured and grew week after week. By contrast, since early March, Wiranto-linked regional commanders like East Java's Maj. Gen. Djadja Suparman had proved much more accommodating, and by early May General Wiranto himself assumed a lead role in the "dialogue" with some student leaders. ${ }^{96}$ A similar split could be discerned in the diverging responses to news that student activists had been abducted and allegations that Armed Forces personnel were responsible. Even as rumors linking the abductions to Lt. Gen. Prabowo and his allies began to circulate in Jakarta, Armed Forces Commander General Wiranto categorically denied official

\footnotetext{
93 See "1998: The Nationwide Student Protest Movement and the Opening to Democratic Reform," in Human Rights Watch/Asia, Academic Freedom in Indonesia: Dismantling Soeharto-Era Barriers (New York: Human Rights Watch/Asia, 1998).

94 See, for example, "Prof. Dr. Ichlasul Amal M.A.: 'Mahasiswa-lah yang Sekarang Punya Power...'," D \& $R$, April 4, 1998, pp. 20-21.

95 "Agar Menjadi people Power?," $D$ \& R, May 2, 1998, pp. 67-68; "Membangun Basis Perjuangan Rakyat," $D \& R$, May 2, 1998, pp. 69-70; "Intifadah Campus Meluas'," D \& R, Mei 2, 1998, p. 71.

96 "Dialog Sebagai Salah Satu Cara," $D$ \& $R$, April 25, 1998, pp. 48-49.
} 
military involvement, condemned whatever "rogue elements" (oknum) had committed such misdeeds, and ordered an immediate investigation into the matter. ${ }^{97}$

It was in the context of these broadening popular protests and deepening regime divisions that the government announced its drastic reduction of fuel prices on the evening of Monday, May 4. ${ }^{98}$ Doubtlessly designed, and perfectly timed, to force IMF approval and disbursement of funds despite misgivings about the pace and extent of reform implementation since the signing of the April 10 accord, this move hiked gasoline prices by 70 percent, diesel by 60 percent, and kerosene by 25 percent literally overnight. ${ }^{99}$

That evening, as the long lines for fuel and the ensuing traffic jams in the streets of Jakarta and Surabaya suggested, macet total was at hand. Student protests swelled and spilled into the streets in several major cities, demonstrators stopped traffic for hours outside the regional assembly in Surabaya, and Medan erupted in rallies and rioting. ${ }^{100}$

With President Suharto out of the country to attend an international conference in Cairo, and rumors circulating of a cabinet reshuffle (or special MPR session) on his return, macet clogged the streets. Student protests continued to grow, and confrontations with police and military authorities became more frequent and more heated. The time for a major traffic diversion and street-clearing operation had arrived. In the late afternoon of May 12, after hours of protests in and around Jakarta's élite Trisakti University, security forces opened fire and shot dead six students, wounding many more. 101 The killings, suspected to be the premeditated handiwork of military elements led by Lt. Gen. Prabowo, generated widespread public outrage. ${ }^{102}$ On May 13, thousands joined a burial ceremony for the slain students, bringing crowds to the streets. Scattered rioting and looting ensued in several parts of Jakarta and other cities, most notably Solo, 103 continued and spread on May 14, and finally petered out the next day. 104

97 "Membentuk Tim, Mencari Penculik," Forum Keadilan, May 4, 1998; "Mayjen TNI (Purn.) Samsudin: 'Apa Mungkin Seorang Jenderal Bisa Melakukan Perbuatan Itu?,' Forum Keadilan, May 4, 1998.

98 "Sudah Jatuh, Tertimpa Tangga Pula," D \& R, May 4, 1998.

99 See "DMF Executive Board Completes First Review of Indonesia's Economic Program," International Monetary Fund News Brief No. 98/11, May 4, 1998; and "International Monetary Fund Press Briefing on First Review of Indonesia's Economic Program by Stanley Fischer and Hubert Neiss," May 4, 1998.

100 See: "Percik Bara Seantero Nusantara," Forum Keadilan, June 1, 1998, pp. 18-20.

101 See: "Di Ujung Aksi Damai," Forum Keadilan, June 1, 1998, pp. 10-16.

102 See, for example, "Si Pelaku Bisa Diketahui Dari Komandanna'," Forum Keadilan, June 1, 1998, pp. 7478; “Misteri, Keanehan, Campur Aduk Dalam Trisakti Berdarah," Gatra, June 13, 1998; "Sidang Penembakan Mahasiswa Trisakti: Keberadaan Pasukan Lain Dipertanyakan," Kompas, June 16, 1998; "Danpomdam Jaya, Kolonel Hendardji: 'Ada Pihak yang Mau Menututup-nutupi Kasus Ini'," Forum Keadilan, June 16, 1998; "Sidang Penembakan Mahasiswa Trisakti: Perintah Tembak Hanya Ada pada Pangdam," Kompas, June 17, 1998; and "Sidang Kasus Trisakti: Ada Tembakan dari Arah Citraland," Kompas, June 25, 1998.

103 Anggit Noegroho and Bambang Harsri Irawan, Rekaman Lensa Peristiwa Mei 1998 Di Solo (Solo: Aksara Solopos, 1998).

104 See, for example, "Jakarta Dilanda Kerusuhan Massa," Kompas, May 14, 1998, p. 1; "Perusuh Menjarah," Kompas, May 15, 1998, p. 1; and "Kerusuhan Makin Hebat: 7 Tewas, ratusan mobil dibakar, toko2 hancur," Pos Kota, May 15, 1998, p. 1. 
The riots were unprecedented in their scope, violence, and impact. Subsequent reports estimated that more than one thousand people had lost their lives, many others had suffered beatings, rapes, and other indignities, and countless shops, homes, and other forms of private property had been lost to burning, looting, and wreckage. ${ }^{105}$ While many of those who died were protesters or looters killed by security forces and/or trapped inside burning buildings, it was the ethnic-Chinese Jakarta residents who were targeted for violent abuse at the hands of the rioters. Ethnic-Chinese were victimized in countless incidents, most notably the raping of more than one hundred women in various parts of Jakarta-acts of violence and brutality unseen in previous riots. ${ }^{106}$ Fearful for their lives, some 150,000 residents (mostly ethnic-Chinese Indonesians and Western expatriates) fled the country, mostly by airplane to nearby Singapore or Hong Kong. ${ }^{107}$

Like the shootings at Trisakti University on May 12, the riots in Jakarta on May 1315 bore traces of Prabowo's handiwork. Numerous eyewitness accounts sketched a pattern of instigation and coordination by groups of men who initiated the rioting and carried out the rapes, described in terms that suggested preman as well as military troops in mufti. ${ }^{108}$ As noted elsewhere in this issue, other evidence linked shady figures like Anton Medan and the anti-Chinese activist Ki Gendeng Pamungkas to rioting in certain areas of Jakarta. ${ }^{109}$ Suspicions about the Trisakti shootings and security forces' behavior during the riots first focussed on Jakarta Regional Commander Maj. Gen. Sjafrie Sjamsoeddin and the Jakarta police chief, Maj. Gen. Pol. Hamami Nata, but subsequent revelations by a member of Special Forces (Kopassus) were later to prove far more sensational. ${ }^{110}$

According to this informant, troops from Kopassus, Kostrad, and Kodam Jaya (the Greater Jakarta Regional Command) had been assembled as early as March 1998 and readied for undercover operations by Prabowo and Sjafrie Sjamsoeddin. Together with Jakarta-based preman and several hundred civilian assets brought in from as far afield as East Timor and Irian Jaya, these forces were then mobilized on May 12 and assigned targets for "riot" activities, including rapes of ethnic-Chinese women. The military operation, under the rubric of a "Gerakan 12 Mei Orde Baru" (May 12 New Order Movement), was apparently intended to disrupt and discredit the popular protests against the regime, justify a harsh military crackdown in Jakarta, and precipitate both

105 See Tim Relawan Untuk Kemanusiaan, Sujud di Hadapan Korban: Tragedi Jakarta Mei 1998 (Jakarta: Divisi Data Tim Relawan, 1998).

106 See Tim Pemburu Fakta, Puncak Kebiadaban Bangsa: Pemerkosaan Etnik Tionghoa 13-14 Mei '98 (Jakarta: Yayasan Karyawan Matra, 1998); and Tim Relawan untuk Kemanusiaan, "Dokumentasi Awal No. 3: Perkosaan Massal dalam Rentetan Kerusuhan," Jakarta, July 13, 1998.

107 "Over 150,000 flee abroad during riots: Ministry," Jakarta Post, June 9, 1998, p. 2.

108 Tim Relawan Untuk Kemanusiaan, "Dokumentasi Awal No. 1: Pola Kerusuhan di Jakarta dan Sekitarnya," (mimeo) Jakarta, June 9, 1998; Tim Relawan Untuk Kemanusiaan, "Dokumentasi Awal No. 2: Status Penjarahan dalam Kerusuhan," (mimeo), Jakarta, June 9, 1998.

109 See, for example, "Ketika Itu Saya di Australia," Tajuk, September 3, 1998, pp. $20-21$.

110 See also "Laporan Akhir Tim Gabungan Pencari Fakta Peristiwa Tanggal 13-15 Mei 1998," (mimeo), Jakarta, October 23, 1998. 
190 John T. Sidel

the immediate dismissal of Wiranto and the elevation of Prabowo and his allies to the top command posts in the Armed Forces. ${ }^{111}$

If such a plot indeed achieved ample tactical success, the consequences of these "riots" spelled strategic defeat. On May 15, the President returned home early from Cairo, security forces began to reassert "law and order" on the streets of Jakarta, and the government restored the fuel subsidies. ${ }^{112}$ Yet with a Cabinet reshuffle reportedly imminent, a final round of rotations at the highest echelons of New Order power was in the offing, albeit not the one foreseen by Prabowo or President Suharto. ${ }^{113}$

Indeed, the lingering horrors of macet in the streets a few days earlier combined with fearful anticipations of imminent and irrevocable mutasi in the civilian and military hierarchies to undermine internal regime solidity in the face of continuing protests and mounting calls for Suharto to step down. In the wake of the riots, prominent figues representing the full spectrum of key élite jaringan-including Adi Sasono, the Secretary General of ICMI-had joined opposition leader Amien Rais in a fifty-member Majelis Amanat Rakyat (MAR or Assembly of the People's Mandate) and called for Suharto's resignation. ${ }^{114}$ Against this backdrop, rising fears of displacement in the imminent reshuffle and contingency plans for a possible Special Session (Sidang Istimewa) of the MPR soon precipitated the withdrawal of support for Suharto from within even the innermost circuitries of the regime. If, as many feared, Mbak Tutut would soon assume the stewardship of Golkar and Lt. Gen. Prabowo Subianto the command of the Armed Forces, the moment for a preemptive strike had arrived.

First to defect were civilian elements loosely affiliated with Habibie, ICMI, and, through this jaringan, the HMI students and Muhammadiyah leaders on the streets. On May 18, the fraction heads of the DPR, including current Golkar chief and DPR speaker Harmoko and Armed Forces fraction leader Lt. Gen. Syarwan Hamid, both Habibie allies, publicly called on the President to resign, thus claiming the hitherto rubberstamp parliament as a new locus of authority and the vice-president as legal successor. ${ }^{115}$ Two days later, with thousands of student protesters still occupying the Parliament grounds, Economic Coordinating Minister Ginandjar Kartasasmita and thirteen other cabinet members submitted their resignations. Like their counterparts in the DPR, many of these ministers enjoyed a close association or tactical alliance with Vice-President Habibie and shared a common distaste for the now ascendant Mbak Tutut and her minions in Golkar, the cabinet, and the parliament.

Meanwhile, in the military establishment a set of counter-moves and a process of internal consolidation appear to have proceeded in response to the emerging disarray and defections in civilian circles. Rumors in early May had suggested growing support

111 See "Saksi Saksi Setelah 100 Hari," Tajuk, September 3, 1998, pp. 16-19; and "TGPF Temukan Indikasi Kopassus Terlibat Kerusuhan," SiaR, September 30, 1998.

112 See, for example, "Menhamkam/Pangab: Situasi Jakarta Sudah Normal, Kompas, May 17, 1998, p. 1; and "Merevisi Dua Keppres Berumur Sebelas Hari," Forum Keadilan, June 1, 1998, pp. 80-85.

113 “Presiden Segera Reshuffle' Kabinet," Kompas, May 17, 1998, p. 1.

114 "Para Tokoh Bentuk Majelis Amanat Rakyat," Kompas, May 15, 1998, pp. 1, 7.

115 “Pimpinan DPR: Sebaiknya Pak Harto Mundur," Kompas, May 19, 1998, p. 1; "Pimpinan DPR: Demi Persatuan, Presiden Sebaiknya Mundur," Republika, May 19, 1998, p. 1; "Presiden Diminta Mundur," Media Indonesia, May 19, 1998, p. 1. 
in top military circles for a cabinet reshuffle or, if necessary, a special session of the MPR, and Armed Forces Chief of Staff for Social and Political Affairs (Kassospol) Lt. Gen. Bambang Susilo Yudhoyono, a close Wiranto ally, had initiated consultations with (mostly PSI-ish) civilians about a package of political reforms. After the Jakarta "riots" and the DPR chiefs' defections, moreover, a series of meetings among the top military brass reportedly led to an emerging consensus in support of the immediate convening of a Dewan Reformasi (Reform Council) and the holding of new elections within a matter of months. ${ }^{116}$ It was perhaps with this plan in mind that General Wiranto publicly rejected parliamentary leaders' May 18 resolution calling for Suharto's immediate resignation and Habibie's assumption of presidential powers.

As the Armed Forces leadership closed ranks behind this political initiative, Lt. Gen. Prabowo Subianto and his allies found themselves outmaneuvered if not quite outgunned. Some reports claim that Prabowo still stood as one of his father-in-law's few remaining avowed defenders in the top Armed Forces brass, while other evidence suggests he supported the pro-Habibie maneuvers at the DPR and in the Cabinet, but in the end his stance did not prove decisive. Prabowo and his allies had assumed command over thousands of Kostrad, Kopassus, and Kodam Jaya troops in Jakarta but did not enjoy broad support within the military leadership. Instead, widely shared resentments and fears of Prabowo, abiding respect for the formal military command hierarchy, as well as crosscutting horizontal and vertical ties among officers appear to have offset his influence and solidified Wiranto's position among the colonels and generals, effectively preempting a coup.

It was thus through an orderly, surgical removal of Suharto that the institutional logic of military mutasi and the pressures of élite civilian jaringan finally flushed out the congestion at the heart of the regime. DPR leaders and opposition protesters had rejected Suharto's promise of new elections, fourteen cabinet seats were now empty, and no credible Dewan Reformasi was in sight, but with Suharto's resignation and Habibie's assumption of the presidency on May 21, kemacetan politik essentially subsided. Subsequent weeks saw the transfer of Prabowo and his allies from the key Kostrad, Kopassus, and Kodam Jaya commands in Jakarta, the process leading to his official discharge, and Gen. Wiranto's belated assertion of effective command over the Armed Forces. Meanwhile, in the Cabinet, Golkar, the DPR, and various state agencies, Habibie began to purge close Suharto family minions and to install members of his own, ICMI-based, jaringan. At last, the single most enduring obstacle to sirkulasi and the impending threat of macet had been removed, and, staged diversions and disruptions aside, it had happened in a surprisingly orderly and fluid fashion. ${ }^{117}$

\footnotetext{
116 Keith B. Richburg, "Seven Days That Toppled a Titan: Back-Room Intrigue Led to Suharto's Fall," Washington Post, May 24, 1998, p. A1.

117 For summaries of these crucial days, see, "Detik-Detik Menjelang Pak Harto Berhenti," Forum Keadilan, June 17, 1998; "Detik-detik Soeharto Berhenti Versi Habibie," Kompas, June 7, 1998; and S. Sinansari ecip, Kronologi Situasi Penggulingan Soeharto" Reportase Jumalistik 72 Jam Yang Menegangkan (Jakarta: Mizan Pustaka, 1998).
} 
192 John T. Sidel

\section{Conclusions}

Months after the events of May 1998, neither the full inside story nor the broad outlines of their long-term consequences can yet be easily discerned, much as was the case in the years in Indonesia after the upheaval of late 1965. Nonetheless, as the preliminary analysis above suggests, some tentative conclusions can already be drawn, sketched against the backdrop of abundant academic research and journalistic reporting on the New Order regime and its demise.

First of all, both the strikingly orderly and fluid process and the unexpected immediate outcome of Suharto's downfall in May 1998 were decisively shaped by underlying institutional logics and sociological trends which crystallized under the New Order. In particular, the steady rotation and retirement of military officers and their recirculation through the civilian corridors of the regime inevitably ran up against the political congestion created by the personal accumulation and entrenchment of Suharto, his family, and his close cronies. Meanwhile, the core civilian circuitries of the regime, long restricted to retired officers, priyayi functionaries, CSIS operatives, and PSI-ish jaringan, were eventually opened up to new flows of (typically HMI-bred) "modernist" Moslem late-comers coursed through Habibie's empire and ICMI. Both the military and the civilian hierarchies operated efficiently as vertical recruitment networks so long as sirkulasi continued, but ultimately provided the institutional pressures and procedures for Suharto's ouster under conditions of incipient macet. The removal of Suharto and his family members from both the military hierarchy and the core civilian circuitries of the regime thus relieved some of the mounting pressures of macet and released long pent-up flows of circulation into the previously restricted innermost corridors of state power.

Secondly, these patterns of steady sirkulasi and impending macet also worked to shape Suharto's response to the economic crisis that began to unfold in the final months of 1997. If in response to previous crises Suharto had opened up new avenues to the circulation that was the life-blood of his regime, by the mid-1990s his inclinations dictated otherwise. Indeed, it was the pattern of personal accumulation and entrenchment by his family that threatened to clog the arteries of state power and the circuitries of the economy, and those forces favoring the easing of sirkulasi were viewed with deep hostility and suspicion. Hence Suharto's unwillingness to implement successive IMF agreements and his staging of various diversions and disruptions instead. In this regard, the anti-"Chinese" campaign, the choice of B. J. Habibie as Vice-President, and the "riots" in Jakarta in May carried the false promise of alternative routes for circulation (and redistribution) to those leading towards the Palace and the President's family.

Thirdly, these patterns of internal regime circulation and management of macet prefigured the short-circuiting of Suharto's strategy within the state and the popular macet in the streets. Staged disruptions and "riots" since the mid-1990s had sidelined those forces least incorporated into New Order élite circulation and capital accumulation but most capable of mass mobilization: Megawati's PDI and her supporters among the urban poor; the SBSI and other labor unions; student and NGO activists linked with the left-ish PRD; and even the lower-middle-class Moslem networks of the Nahdlatul Ulama. These "riots" undermined attempts at popular 
mobilization, pathologized the appearance of "the people" on the streets, and pitted the energies of the excluded against the putatively alien "Chinese."

Meanwhile, the regime's creation and cultivation of a new jaringan for Moslem incorporation and ascendancy within the circuitries of state power and capital accumulation served to stimulate-and legitimate-popular energies that could be channeled but never fully contained. Habibie's huge empire and ambitions, and the expanding reach of ICMI, ran up against the ceiling imposed by the Suharto family's entrenchment in core state circuitries and their enormous private konglomerasi, generating disappointment and disillusionment with the regime. Hence the prominence of Amien Rais and a network of HMI activists (and prominent alumni) in the ranks of the opposition, and the eventual defection of pro-Habibie forces from Suharto. On college campuses throughout the country, and in the innermost corridors of power, "modernist" Moslems succeeded in identifying their aspirations in broader, more public and inclusive terms, in line with the other insurgent jaringan and against the narrow interests of the Palace.

Fourthly and finally, the nature of the transition in May 1998 left the broader problems of sirkulasi and macet unresolved. Today, even as the Suharto family's konglomerasi and patronage networks within the state are being dismantled, General Wiranto has remained as both Defense Minister and Armed Forces Commander, and the military establishment has retained many of its considerable powers over personnel and policy within the Indonesian state. Meanwhile, members of Habibie's ICMI-based jaringan have begun to entrench themselves in the civilian circuitries of the regime-Golkar, the DPR, the Cabinet, and key state milking cows. An uneasy duumvirate based on these two hierarchies has now survived for several months, brokered by cabinet ministers closely linked to Habibie and ICMI circles but also enjoying residual influence in the military.

Against such tendencies towards the crystallization and entrenchment of a new authoritarian regime stands a broad array of social forces now mobilizing for elections in 1999. The strongest oppositional forces, perhaps unsurprisingly, are to be found among those public figures whose prominence and power emanates not from their inclusion in the circuitries of state power but from a popular base. Such figures as Megawati Soekarnoputri and Gus Dur, for example, can claim not only direct lineages to two major political parties of the pre-Suharto era, but a deeper affinity for dynasty building than for jaringan links, for private accumulation instead of circulation within the state. Firmly rooted both in the popular imagination and in enduring local oligarchies, these figures may represent the promise-and the limitations-of the liberal democratic politics to come.

Yet, as recent riots and other disruptions have suggested, the patterns of elite circulation and macet management which evolved in the course of the New Order may well have survived the passing of Suharto from the scene. Popular pressures for-and official promises of- "Reformasi" notwithstanding, the Armed Forces leadership has retained considerable prerogatives in politics and is unlikely to surrender its privileged position in state and society overnight. Meanwhile, the configuration of political alliances within the broad realm of "modernist" Moslem jaringan has remained in considerable flux, with Amien Rais and many of his followers in Muhammadiyah now committed to a broadly inclusive, PSI-ish party but perhaps still available for a merger 
194 John T. Sidel

with more Masjumi-ish groupings and/or incorporation into regime circuitries (even Golkar) now more thoroughly, albeit narrowly, "Islamic." After all, for many in such jaringan, there remains a broad field of compatability between a heavily étatiste industrial strategy, a dominant- or one-party regime, and a program of social advancement for Moslems.

Beyond such issues of élite circulation lurks a set of larger questions about the place of capital in a post-Suharto Indonesia. Even after many years of rapid industrialization and economic growth under the New Order, the Indonesian capitalist class remained politically servile, compromised, and vulnerable, due to the problematic "alien" status of "Chinese" businessmen and the reliance on state largesse of their typically well-connected pribumi ("indigenous") competitors. Thus, as students and prominent intellectuals rallied behind "Reformasi" in the streets and military officers and civilian politicians plotted in the corridors of power in early-mid May 1998, most Indonesian businessmen remained on the sidelines, whether in virtual hiding in Jakarta or in hotels in Hong Kong or Singapore.

In these early months of the post-Suharto era, moreover, the political position of capital in Indonesia remains a pivotal if as yet unanswerable question. The 1999 elections, after all, may offer an unprecedented opportunity for business "investment" in opposition politicians and the institutions of liberal democracy, or, alternatively, yet another shakedown by Golkar and its Army backers. If Barrington Moore, Jr. was right, and if the Southeast Asian examples of Thailand and the Philippines are any guide, a politically "vigorous and independent" - if not ethnically assimilatedcapitalist class will be necessary for a stable liberal democracy. Yet the hopes and pressures for "Demokrasi" in Indonesia today push for political change far beyond the crass money politics and local bossism found in such nearby post-authoritarian democracies in the region. Under the nervous but still vigilant gaze of the policemen, traffic is flowing again on the streets but there are new forms of macet still to come. 